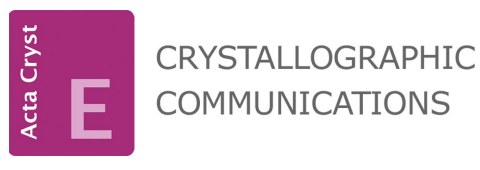

ISSN 2056-9890

Received 10 June 2020

Accepted 11 June 2020

Edited by W. T. A. Harrison, University of Aberdeen, Scotland

₹ Additional correspondence author, e-mail: edwardt@sunway.edu.my.

Keywords: crystal structure; pyrrolidine; Hirshfeld surface analysis; $\mathrm{NCl}$ plots; computational chemistry.

CCDC reference: 2009242

Supporting information: this article has supporting information at journals.iucr.org/e
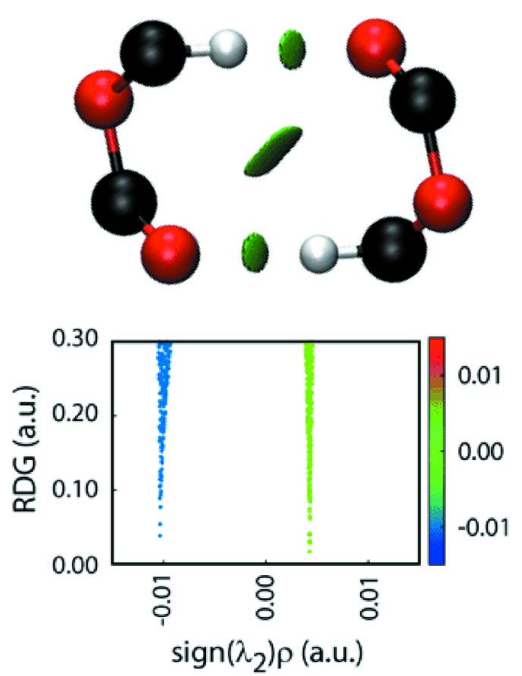

OPEN Ә ACCESS

\section{4-Nitrobenzyl 3,4-bis(acetyloxy)-2-(4-methoxy- phenyl)pyrrolidine-1-carboxylate: crystal structure, Hirshfeld surface analysis and computational chemistry}

Sofia Dallasta Pedroso, ${ }^{a}$ Ignez Caracelli, ${ }^{b_{*}}$ Julio Zukerman-Schpector, ${ }^{a}$ Monica Soto-Monsalve, ${ }^{c}$ Regina H. De Almeida Santos, ${ }^{\text {c }}$ Carlos Roque D. Correia, ${ }^{\text {d }}$ Ariel L. Llanes Garcia, ${ }^{d}$ Huey Chong Kwong ${ }^{\mathrm{e}}$ and Edward R. T. Tiekink ${ }^{\mathrm{e}}$ '

\footnotetext{
a'Laboratório de Cristalografia, Esterodinâmica e Modelagem Molecular, Departamento de Química, Universidade Federal de São Carlos, 13565-905 São Carlos, SP, Brazil, 'b Departmento de Física, Universidade Federal de São Carlos, 13565905 São Carlos, SP, Brazil, 'Instituto de Química de São Carlos, Universidade de São Paulo, São Carlos, SP, Brazil, 'Instituto de Química, Universidade Estadual de Campinas, UNICAMP, C.P. 6154, CEP 13084-917 Campinas, Brazil, and ${ }^{\mathbf{e}}$ Research Centre for Crystalline Materials, School of Science and Technology, Sunway University, 47500 Bandar Sunway, Selangor Darul Ehsan, Malaysia. *Correspondence e-mail: ignez@df.ufscar.br
}

The title compound, $\mathrm{C}_{23} \mathrm{H}_{24} \mathrm{~N}_{2} \mathrm{O}_{9}$, is a tetra-substituted pyrrolidine derivative with a twisted conformation, with the twist evident in the $\mathrm{C}-\mathrm{C}$ bond bearing the adjacent acetyloxy substituents. These are flanked on one side by a C-bound 4-methoxyphenyl group and on the other by a methylene group. The almost $s p^{2}$ $\mathrm{N}$ atom [sum of angles $=357^{\circ}$ ] bears a 4-nitrobenzyloxycarbonyl substituent. In the crystal, ring-methylene- $\mathrm{C}-\mathrm{H} \cdots \mathrm{O}$ (acetyloxy-carbonyl) and methylene- $\mathrm{C}-$ $\mathrm{H}$... $\mathrm{O}$ (carbonyl) interactions lead to supramolecular layers lying parallel to (101); the layers stack without directional interactions between them. The analysis of the calculated Hirshfeld surfaces indicates the combined importance of $\mathrm{H} \cdots \mathrm{H}(42.3 \%), \mathrm{H} \cdots \mathrm{O} / \mathrm{O} \cdots \mathrm{H}(37.3 \%)$ and $\mathrm{H} \cdots \mathrm{C} / \mathrm{C} \cdots \mathrm{H}(14.9 \%)$ surface contacts. Further, the interaction energies, largely dominated by the dispersive term, point to the stabilizing influence of $\mathrm{H} \cdots \mathrm{H}$ and $\mathrm{O} \cdots \mathrm{O}$ contacts in the interlayer region.

\section{Chemical context}

The structure of the title tetra-substituted pyrrolidine derivative, (I), was determined in connection with our on-going structural studies characterizing key synthetic intermediates in the synthesis of various $\alpha$-glucosidase inhibitors (ZukermanSchpector et al., 2017; Dallasta Pedroso et al., 2020). $\alpha$ Glucosidase inhibitors are an important class of drugs employed in the treatment of a variety of diseases such as cancer, cystic fibrosis, diabetes and influenza (Kiappes et al., 2018; Dhameja \& Gupta, 2019).<smiles>COc1ccc(C2C(OC(C)=O)C(OC(C)=O)CN2C(=O)OCc2ccc([N+](=O)[O-])cc2)cc1</smiles> 
More specifically, (I) was generated during a study designed to synthesize the hydroxylated proline derivative, $(2 R, 3 S, 4 R)$ 3,4-dihydroxypyrrolidine-2-carboxylic acid, (II) (Garcia, 2008). In addition to being an $\alpha$-glucosidase inhibitor, (II) is also found as a sub-structure of natural bioactive compounds such as, for example, a component of the repeated decapeptide sequence of the adhesive protein Mytilus edulis foot protein 1 (Mefp1), which is produced by the marine mussel Mytilus edulis and is responsible for the fixation capacity of the mussel to rock (Taylor \& Weir, 2000). The synthetic study determined that in the final stages of the reaction sequence towards (II), it was not possible to smoothly remove the Nbound 4-nitrobenzyloxycarbonyl (PNZ) protecting group via catalytic hydrogenation as the ensuing mixture was difficult to purify. Therefore, it proved necessary to remove the PNZ protecting group through acid hydrolysis at reflux temperature, resulting in a low overall yield (34\%) suggesting that there was no advantage in using PNZ.

The crystal and molecular structures of (I) are described herein with this experimental study complemented by a detailed analysis of the molecular packing by a combination of Hirshfeld surface analysis, non-covalent interaction plots and computational chemistry.

\section{Structural commentary}

The molecular structure of (I), Fig. 1, is constructed about a tetra-substituted pyrrolidine ring with a N1-bound (4-nitrophenyl)ethylcarboxylate group and, respectively, C1-C3bound 4-methoxyphenyl, acetyloxy and acetyloxy substituents. For the illustrated molecule, Fig. 1, the chirality of the C1-C3 atoms follows the sequence $R, R$ and $S$, but it is noted that due crystal symmetry, the centrosymmetric unit cell contains equal numbers of the enantiomers. The conformation of the fivemembered ring is twisted about the $\mathrm{C} 2-\mathrm{C} 3$ bond with the $\mathrm{C} 1-\mathrm{C} 2-\mathrm{C} 3-\mathrm{C} 4$ torsion angle being $39.70(16)^{\circ}$, consistent with a (+)syn-clinal configuration. The sum of the angles about the $\mathrm{N} 1$ atom is $356.7^{\circ}$, indicating an approximate $s p^{2}$ centre.

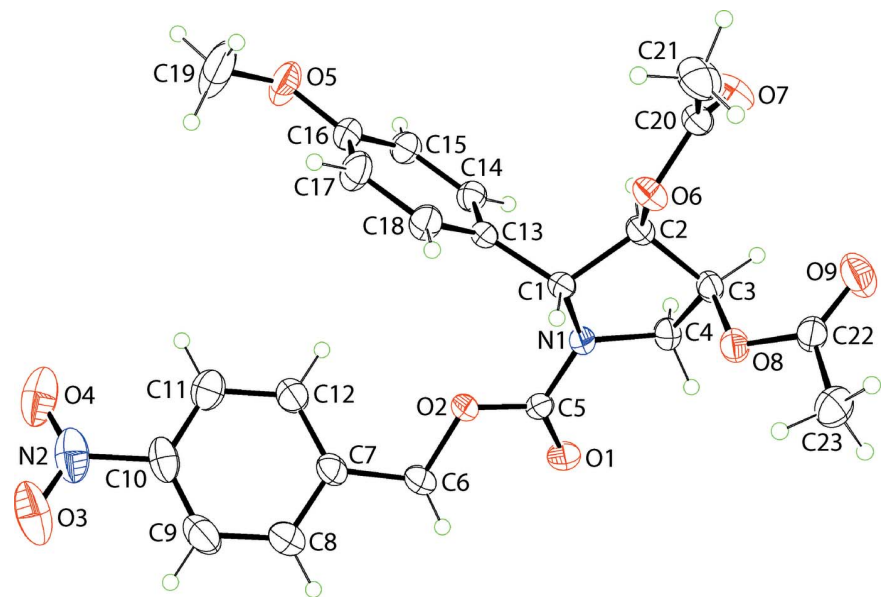

Figure 1

The molecular structure of (I), showing the atom-labelling scheme and displacement ellipsoids at the $35 \%$ probability level.
Table 1

Hydrogen-bond geometry $\left(\AA{ }^{\circ}\right)$.

\begin{tabular}{lllll}
\hline$D-\mathrm{H} \cdots A$ & $D-\mathrm{H}$ & $\mathrm{H} \cdots A$ & $D \cdots A$ & $D-\mathrm{H} \cdots A$ \\
\hline $\mathrm{C} 4-\mathrm{H} 4 B \cdots \mathrm{O} 7^{\mathrm{i}}$ & 0.97 & 2.60 & $3.129(2)$ & 115 \\
$\mathrm{C} 6-\mathrm{H} 6 A \cdots \mathrm{O} 1^{\mathrm{ii}}$ & 0.97 & 2.54 & $3.250(2)$ & 130 \\
\hline
\end{tabular}

Symmetry codes: (i) $-x+\frac{1}{2}, y-\frac{1}{2},-z+\frac{3}{2}$; (ii) $-x+1,-y,-z+2$.

The N1-bound group occupies an equatorial position with those at the $\mathrm{C} 1-\mathrm{C} 3$ centres being bisectional, equatorial and axial, respectively (Spek, 2020). When viewed towards the approximate plane through the pyrrolidine ring, the N-bound carboxylate group is approximately co-planar, i.e. excluding the nitrobenzene residue. The $\mathrm{C} 1$-substituent lies to the opposite side of the plane than the $\mathrm{C} 2$ and $\mathrm{C} 3$-acetyloxy groups; the dihedral angle between the acetyloxy $\mathrm{CO}_{2}$ planes is $57.7(2)^{\circ}$.

With respect to the least-squares plane through the pyrrolidine ring, the nitrobenzene and methoxybenzene rings are splayed, as seen in the dihedral angles of $58.58(8)$ and $77.65(6)^{\circ}$, respectively; the dihedral angle between the benzene rings is $50.56(5)^{\circ}$. There is a twist in the nitrobenzene ring as seen in the value of the $\mathrm{C} 11-\mathrm{C} 10-\mathrm{N} 2-\mathrm{O} 4$ torsion angle of $17.7(3)^{\circ}$. By contrast, the methoxy group is co-planar with the ring to which it is connected, as shown by the $\mathrm{C} 15-$ C16-O5-C19 torsion angle of $176.2(2)^{\circ}$.

\section{Supramolecular features}

The only directional non-covalent interactions of note in the crystal of (I) are two weak $\mathrm{C}-\mathrm{H} \cdots \mathrm{O}$ contacts as listed in Table 1 . The presence of ring-methylene- $\mathrm{C} 4-\mathrm{H} \cdots \mathrm{O}$ 7 (acetyloxy-carbonyl) interactions lead to helical chains along the $b$ axis direction, being propagated by $2_{1}$ symmetry. The other interactions falling within the distance criteria of PLATON (Spek, 2020) are methylene-C6-H -.OO1(carbonyl) interactions, formed between centrosymmetrically related (4nitrophenyl)ethylcarboxylate groups, which lead to the formation of ten-membered $\{\cdots \mathrm{OCOCH}\}_{2}$ synthons. These serve to connect the helical chains into a layer lying parallel to (101), Fig. 2(a). A view of the unit-cell contents is shown in Fig. 2(b), highlighting the stacking of layers, without directional interactions between them.

\section{Non-covalent interaction plots}

The aforementioned weak $\mathrm{C}-\mathrm{H} \cdots \mathrm{O}$ contacts identified in Supramolecular features were also evaluated by calculating non-covalent interaction plots (Johnson et al., 2010; Contreras-García et al., 2011). In short, these calculations indicate whether non-bonding contacts are attractive, weakly attractive or repulsive. The methylene- $\mathrm{C} 6-\mathrm{H}$-..OO1(carbonyl) interactions giving rise to the ten-membered $\{\cdots \mathrm{OCOCH}\}_{2}$ synthons are highlighted in the upper view of Fig. 3(a) with the green isosurface between the interacting atoms and the distinctive blue feature in the reduced density gradient (RDG) 

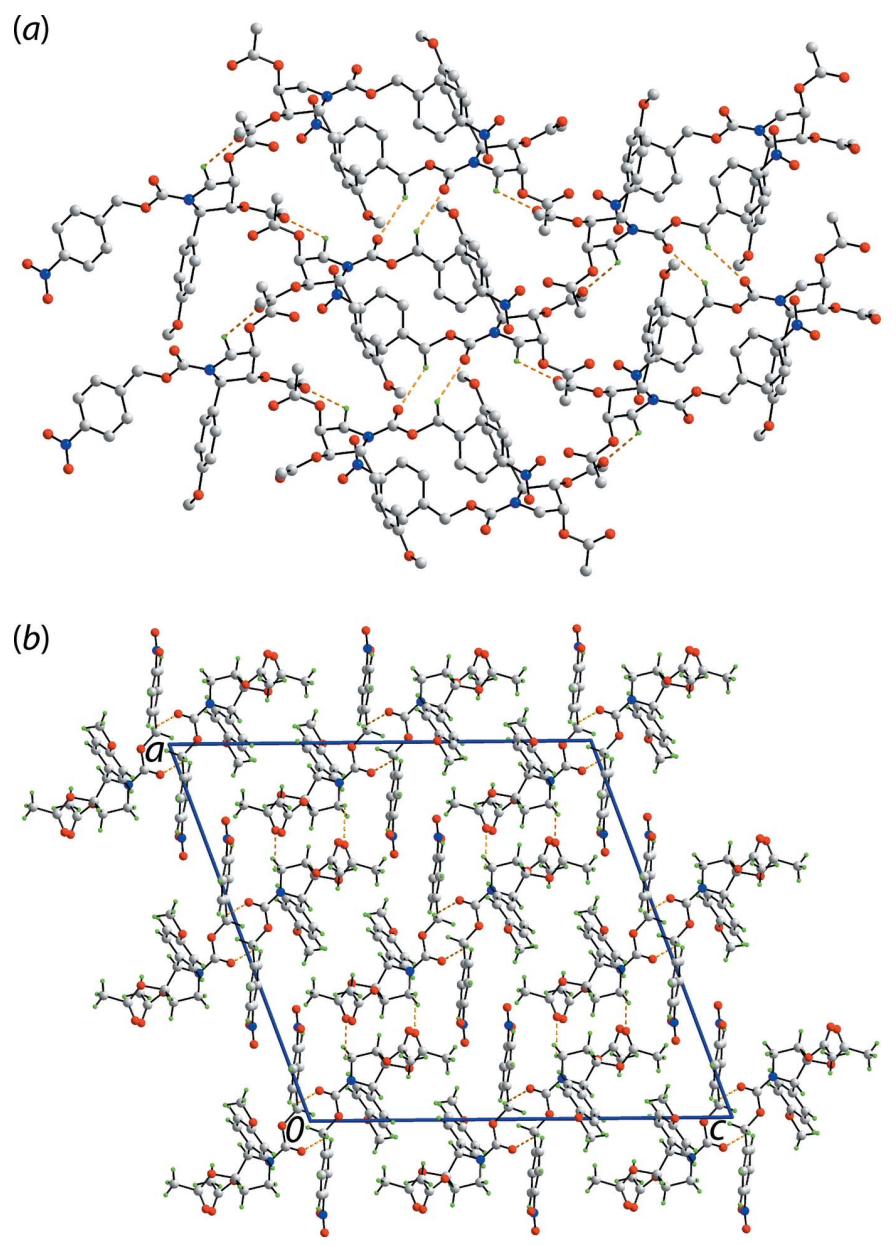

Figure 2

Molecular packing in (I): (a) supramolecular layer parallel to (101) sustained by methylene- $\mathrm{C}-\mathrm{H} \cdots \mathrm{O}$ (carbonyl) contacts shown as orange dashed lines (non-participating $\mathrm{H}$ atoms are omitted) and $(b)$ view of the unit-cell contents shown in projection down the $b$ axis.

versus $\operatorname{sign}\left(\lambda^{2}\right) \rho(r)$ plot in the lower view, i.e. indicating the density value is less than 0.0 a.u., suggest these interactions are weakly attractive. The same is true for the ring-methylene- (a)
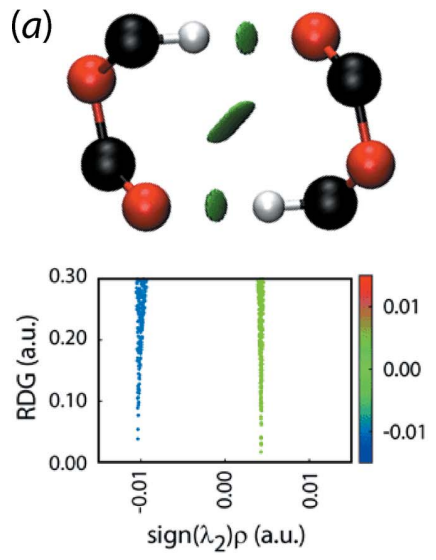

(b)
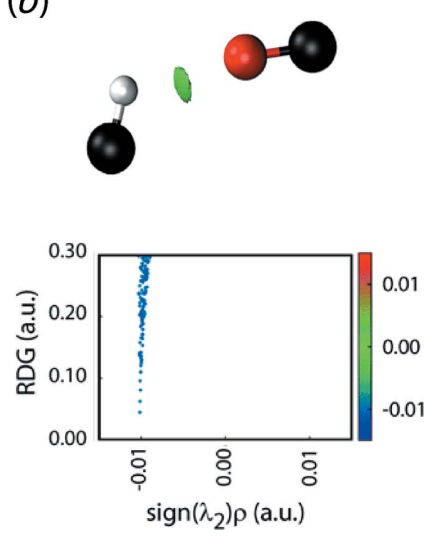

Figure 3

Non-covalent interaction plots for the following interactions in (I): (a) methylene-C6-H.OO1(carbonyl) and (b) ring-methylene-C4$\mathrm{H} \cdot \mathrm{O}$. (acetyloxy-carbonyl).
Table 2

Summary of short interatomic contacts $(\AA)$ in $(\mathrm{I})^{a}$.

\begin{tabular}{lll}
\hline Contact & Distance & Symmetry operation \\
\hline $\mathrm{C} 6-\mathrm{H} 6 A \cdots \mathrm{O} 1^{b}$ & 2.47 & $-x+1,-y,-z+2$ \\
$\mathrm{C} 4-\mathrm{H} 4 B \cdots 7^{b}$ & 2.55 & $-x+\frac{1}{2}, y-\frac{1}{2},-z+\frac{3}{2}$ \\
$\mathrm{C} 4 \cdots \mathrm{O} 7$ & 3.13 & $-x+\frac{1}{2}, y+\frac{1}{2},-z+\frac{3}{2}$ \\
$\mathrm{C} 5 \cdots \mathrm{O} 5$ & 3.08 & $x, y-1, z$ \\
$\mathrm{O} 2 \cdots \mathrm{O} 5$ & 3.02 & $x, y-1, z$ \\
$\mathrm{C} 6-\mathrm{H} 6 B \cdots \mathrm{C} 15$ & 2.73 & $-x+1,-y+1,-z+2$ \\
$\mathrm{C} 9-\mathrm{H} 9 \cdots \mathrm{C} 21$ & 2.75 & $x+\frac{1}{2},-y+\frac{1}{2}, z+\frac{1}{2}$ \\
$\mathrm{O} 4 \cdots \mathrm{O} 4$ & 2.75 & $-x+\frac{3}{2},-y+\frac{3}{2},-z+2$ \\
$\mathrm{H} 17 \cdots \mathrm{H} 23 B$ & 2.35 & $-x+1, y+1,-z+\frac{3}{2}$ \\
\hline
\end{tabular}

Notes: (a) The interatomic distances are calculated in Crystal Explorer 17 (Turner et al., 2017) whereby the $X-\mathrm{H}$ bond lengths are adjusted to their neutron values. (b) These interactions correspond to the interactions listed in Table 1.

$\mathrm{C} 4-\mathrm{H} \cdots \mathrm{O} 7$ (acetyloxy-carbonyl) interactions that lead to the helical chain, Fig. 3(b).

\section{Hirshfeld surface analysis}

The Hirshfeld surface analysis of (I) involved the calculation of the $d_{\text {norm }}$-surface plots, electrostatic potential (calculated using the STO-3G basis set at the Hartree-Fock level of theory) and two-dimensional fingerprint plots following literature procedures (Tan et al., 2019) using Crystal Explorer 17 (Turner et al., 2017). The weak methylene-C6-H... $\mathrm{O} 1$ (carbonyl) interactions are reflected as bright-red spots near the methylene-H6A and carbonyl-O1 atoms on the $d_{\text {norm }}{ }^{-}$ surface plot of (I) shown in Fig. 4. Additional diffuse red spots are also noted near the methoxy-O5 and carbonyl-O7 atoms in Fig. 4, which reflect their participation in short C5 . O 5 and C4. . O 7 contacts with separations $\sim 0.1 \AA$ shorter than the sum of their van der Waals radii, Table 2. Further, faint spots near atom $\mathrm{H} 4 B$ as well as the $\mathrm{O} 5$ and $\mathrm{O} 7$ atoms (each difficult to discern in Fig. 4) are attributed to methylene-C4-

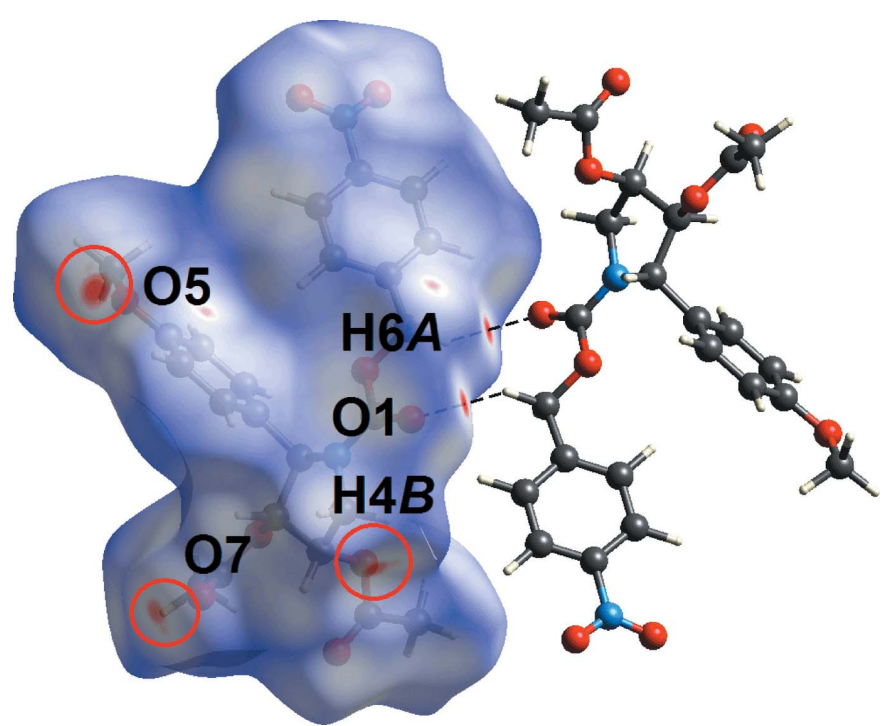

Figure 4

A view of the Hirshfeld surface mapped for (I) over $d_{\text {norm }}$ in the range -0.090 to +1.583 arbitrary units showing the $\mathrm{C}-\mathrm{H} \cdots \mathrm{O}$ interactions as black dashed lines. 
Table 3

Percentage contributions of interatomic contacts to the Hirshfeld surface for (I).

\begin{tabular}{lr}
\hline Contact & Percentage contribution \\
\hline $\mathrm{H} \cdots \mathrm{H}$ & 42.3 \\
$\mathrm{H} \cdots \mathrm{O} / \mathrm{O} \cdots \mathrm{H}$ & 37.3 \\
$\mathrm{H} \cdots \mathrm{C} / \mathrm{C} \cdots \mathrm{H}$ & 14.9 \\
$\mathrm{O} \cdots \mathrm{O}$ & 2.1 \\
$\mathrm{O} \cdots \mathrm{C} / \mathrm{C} \cdots \mathrm{O}$ & 1.2 \\
Others & 2.2 \\
\hline
\end{tabular}

$\mathrm{H} 4 B \cdots \mathrm{O} 7$ (carbonyl) and $\mathrm{O} 2 \cdots \mathrm{O} 5$ short contacts, being $\sim 0.02 \AA$ shorter than their respective sums of the van der Waals radii, Table 2 .

In the views of Fig. 5, the faint red spots that appear near the methylene (H6B), benzyl (C15 and H9), methyl (C21) and nitro (O4) atoms correspond to long-range intra-layer methylene-C6-H6B ‥C15(benzyl), benzyl-C9-H9... C21(methyl) interactions and inter-layer O4...O4 short contacts, Table 2. The Hirshfeld surface mapped over the electrostatic potential in Fig. 6 highlights the donors and acceptors of the indicated interactions through blue (positive electrostatic potential) and red (negative electrostatic potential), respectively.

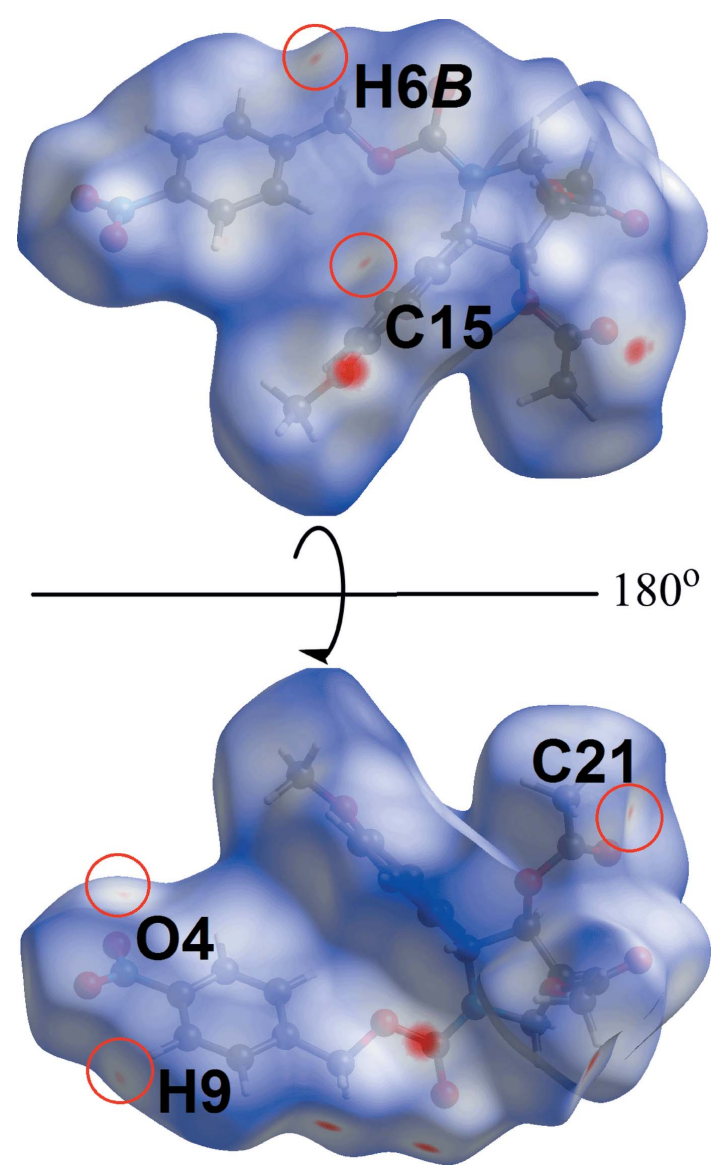

Figure 5

Two views of the Hirshfeld surface mapped over $d_{\text {norm }}$ for (I) in the range -0.090 to +1.583 arbitrary units, highlighting evidence for long-range $\mathrm{C}-$ $\mathrm{H} \cdots \mathrm{C}$ interactions and $\mathrm{O} \cdots \mathrm{O}$ short contacts within red circles (see text).

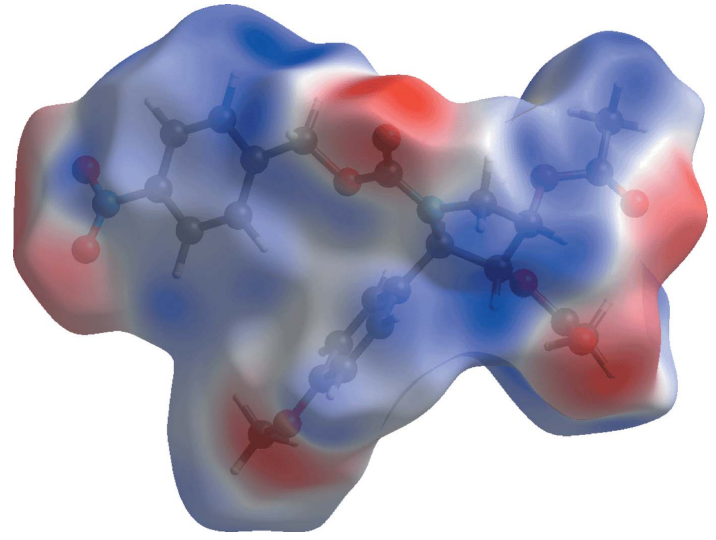

Figure 6

A view of the Hirshfeld surface mapped over the calculated electrostatic potential for (I). The potentials were calculated using the STO-3 G basis set at the Hartree-Fock level of theory over a range of -0.067 to 0.040 a.u. The red and blue regions represent negative and positive electrostatic potentials, respectively.

As illustrated in Fig. 7(a), the two-dimensional fingerprint plot for the Hirshfeld surface of (I) is shown in the upper left and lower right sides of the $d_{\mathrm{e}}$ and $d_{\mathrm{i}}$ diagonal axes, and those delineated into $\mathrm{H} \cdots \mathrm{H}, \mathrm{H} \cdots \mathrm{O} / \mathrm{O} \cdots \mathrm{H}, \mathrm{H} \cdots \mathrm{C} / \mathrm{C} \cdots \mathrm{H}, \mathrm{O} \cdots \mathrm{O}$ and $\mathrm{O} \cdots \mathrm{C} / \mathrm{C} \cdots \mathrm{O}$ contacts are illustrated in Fig. $7(b)-(f)$, respectively. The percentage contributions from different interatomic contacts are summarized in Table 3 . The $\mathrm{H} \cdots \mathrm{H}$ contacts contribute $42.3 \%$ to the overall Hirshfeld surface with the shortest contact, manifested in the round-shape peak tipped at $d_{\mathrm{e}}=d_{\mathrm{i}} \sim 2.4 \AA$, Fig. $7(b)$, corresponding to the $\mathrm{H} 17 \cdots \mathrm{H} 23 B$ inter-layer contact listed in Table 2. The $\mathrm{H} \cdots \mathrm{O} /$ $\mathrm{O} \cdot \mathrm{H}$ contacts contribute $37.3 \%$ to the overall Hirshfeld surface, reflecting the significant $\mathrm{C}-\mathrm{H}$. . O contacts evident in the packing, Tables 1 and 2 . The shortest contacts are reflected as two sharp spikes at $d_{\mathrm{e}}+d_{\mathrm{i}} \sim 2.5 \AA$ in Fig. $7(c)$. The $\mathrm{H} \cdots \mathrm{C} /$ $\mathrm{C} \cdots \mathrm{H}$ contacts that match the long-range $\mathrm{C}-\mathrm{H} \cdots \mathrm{C}$ inter- (a)

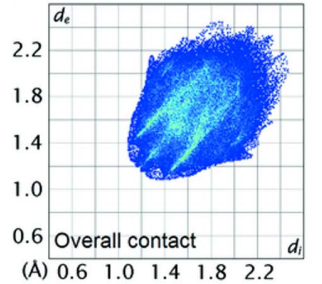

(d)

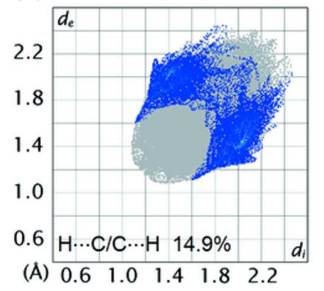

(b)

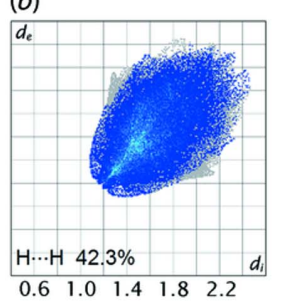

$(e)$

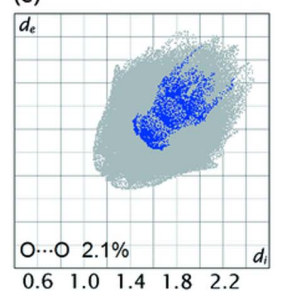

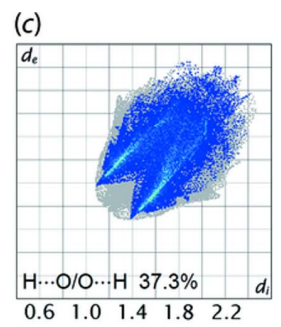

$(f)$

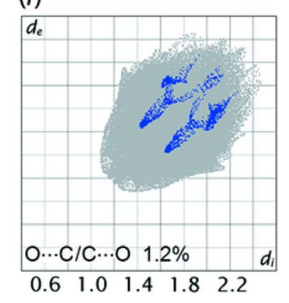

Figure 7

(a) The full two-dimensional fingerprint plot for $(\mathrm{I})$ and $(b)-(f)$ those delineated into $\mathrm{H} \cdots \mathrm{H}, \mathrm{H} \cdots \mathrm{O} / \mathrm{O} \cdots \mathrm{H}, \mathrm{H} \cdots \mathrm{C} / \mathrm{C} \cdots \mathrm{H}, \mathrm{O} \cdots \mathrm{O}$ and $\mathrm{O} \cdots \mathrm{C} /$ C.. O contacts, respectively. 
Table 4

Summary of interaction energies $\left(\mathrm{kJ} \mathrm{mol}^{-1}\right)$ calculated for $(\mathrm{I})$.

\begin{tabular}{|c|c|c|c|c|c|c|}
\hline Contact & $R(\AA)$ & $E_{\text {ele }}$ & $E_{\mathrm{pol}}$ & $E_{\text {dis }}$ & $E_{\text {rep }}$ & $E_{\text {tot }}$ \\
\hline \multicolumn{7}{|l|}{ Intra-layer region } \\
\hline $\mathrm{C} 4 \cdots \mathrm{O}^{\mathrm{i}}$ & 10.99 & -17.8 & -6.1 & -29.1 & 18.3 & -37.3 \\
\hline $\begin{array}{l}\mathrm{C} 6-\mathrm{H} 6 A \cdots \mathrm{O} 1^{\mathrm{ii}} \\
\mathrm{C} 5 \cdots 5^{\mathrm{iii}}+\end{array}$ & 9.21 & -23.8 & -6.9 & -23.2 & 21.7 & -37.0 \\
\hline $\mathrm{O} 2 \cdots \mathrm{O}^{\mathrm{iii}}$ & 8.29 & -8.4 & -2.7 & -56.3 & 29.1 & -41.8 \\
\hline $\begin{array}{l}\mathrm{C} 9-\mathrm{H} 9 \cdots \mathrm{C} 21^{\mathrm{iv}} \\
\mathrm{C} 6-\mathrm{H} 6 B \cdots \mathrm{C} 15^{\mathrm{v}}+\end{array}$ & 14.12 & -12.7 & -3.4 & -20.5 & 12.0 & -26.4 \\
\hline $\mathrm{C} 4-\mathrm{H} 4 A \cdots \mathrm{O} 4^{\mathrm{v}}$ & 6.55 & -18.1 & -4.5 & -87.1 & 52.8 & -65.8 \\
\hline $\begin{array}{l}\mathrm{C} 21-\mathrm{H} 21 C \cdots \mathrm{O} 4^{\mathrm{vi}} \\
\text { Inter-laver region }\end{array}$ & 15.04 & -2.1 & -1.0 & -3.7 & 1.5 & -5.2 \\
\hline $\begin{array}{l}\text { Inter-layer region } \\
\mathrm{H} 17 \cdots \mathrm{H} 23 B^{\text {vii }} \\
\mathrm{H} 17 \cdots \mathrm{H} 21 B^{\text {vii }}+\end{array}$ & 10.38 & 2.9 & -1.2 & -16.5 & 8.2 & -7.1 \\
\hline $\mathrm{H} 18 \cdots \mathrm{H} 21 B^{\text {viii }}$ & 6.24 & -1.1 & -1.6 & -52.9 & 23.0 & -34.2 \\
\hline $\mathrm{O} 4 \cdots \mathrm{O} 4^{\mathrm{ix}}$ & 13.71 & -16.1 & -4.4 & -16.2 & 10.8 & -27.7 \\
\hline $\mathrm{C} 8-\mathrm{H} 8 \cdots \mathrm{O}^{x}$ & 12.70 & -5.4 & -1.3 & -10.2 & 1.9 & -14.4 \\
\hline
\end{tabular}

Symmetry codes: (i) $-x+\frac{1}{2}, y-\frac{1}{2},-z+\frac{3}{2}$; (ii) $-x+1,-y,-z+2$; (iii) $x, y-1$, $z$; (iv) $x+\frac{1}{2}$, $-y+\frac{1}{2}, z+\frac{1}{2}$; (v) $-x+1,-y+1,-z+2$; (vi) $x-\frac{1}{2},-y+\frac{3}{2}, z-\frac{1}{2}$; (vii) $-x+1, y+1,-z+\frac{3}{2}$; (viii) $-x+1, y,-z+\frac{3}{2}$; (ix) $-x+\frac{3}{2},-y+\frac{3}{2},-z+2 ;(x)-x+\frac{3}{2},-y+\frac{1}{2},-z+2$.

actions discussed above are shown as a pairs of forceps-like tips at $d_{\mathrm{e}}+d_{\mathrm{i}} \sim 2.7 \AA$ in the fingerprint plot delineated into $\mathrm{H} \cdots \mathrm{C} / \mathrm{C} \cdots \mathrm{H}$ contacts, Fig. $7(d)$. Although both $\mathrm{O} \cdots \mathrm{O}$ and $\mathrm{O} \cdots \mathrm{C} / \mathrm{C} \cdots \mathrm{O}$ contacts appear at $d_{\mathrm{e}}+d_{\mathrm{i}} \sim 3.0 \AA$ in the respective fingerprint plots, Fig. $7(e)$ and $(f)$, their contributions to the overall Hirshfeld surface are only 2.1 and $1.2 \%$, respectively. The other interatomic contacts have a negligible effect on the molecular packing as their accumulated contribution is about $2.2 \%$.

\section{Energy frameworks}

The pairwise interaction energies between the molecules in the crystal of (I) were calculated by summing up four energy components, comprising the electrostatic $\left(E_{\text {ele }}\right)$, polarization $\left(E_{\mathrm{pol}}\right)$, dispersion $\left(E_{\mathrm{dis}}\right)$ and exchange-repulsion $\left(E_{\mathrm{rep}}\right)$ energies as per the literature (Turner et al., 2017). In the present study, the energy framework of (I) was generated by employing the 6-31G $(d, p)$ basis set with the B3LYP function. The individual energy components as well as the total inter- action energies are collated in Table 4. As anticipated, the dispersive component makes the major contribution to the interaction energies owing to the absence of conventional hydrogen bonding in the crystal. The most significant stabilization energies are found in the intra-layer region and arise from the directional contacts outlined in Hirshfeld surface analysis as well as two additional $\mathrm{C}-\mathrm{H} \cdots \mathrm{O}$ interactions, i.e. methylene-C4-H4A ‥ 4 (nitro) and methyl-C21-H21C.. O4(nitro) with $\mathrm{H} \cdots \mathrm{O}$ separations of 2.63 and $2.77 \AA$, respectively.

The stabilization energies in the inter-layer region are also dominated by the $E_{\mathrm{dis}}$ terms associated with the $\mathrm{H} \cdots \mathrm{H}$ contacts as well as the long-range $\mathrm{C}-\mathrm{H} \cdots \mathrm{O}$ interactions $\left(-14.4 \mathrm{~kJ} \mathrm{~mol}^{-1}\right)$. For the former, the maximum energy is not found for the shortest $\mathrm{H} 17 \cdots \mathrm{H} 23 B$ contact $\left(-7.1 \mathrm{~kJ} \mathrm{~mol}^{-1}\right)$, Table 2 and Fig. $8(b)$, but rather for a pair of benzene$\mathrm{H} \cdots \mathrm{H}$ (methyl) interactions occurring in close proximity in a hydrogen-rich region but at longer separations $\left(-34.2 \mathrm{~kJ} \mathrm{~mol}^{-1}\right)$. For the inter-layer O4..O4 contact mentioned above, there are almost equal contributions from $E_{\text {ele }}$ and $E_{\text {dis }}$, Table 4 , giving rise to a total interaction energy of $-27.7 \mathrm{~kJ} \mathrm{~mol}^{-1}$. The magnitudes of intermolecular energies are represented graphically in Fig. 8, and clearly demonstrate the dominance of the $E_{\text {dis }}$ in the molecular packing.

\section{Database survey}

There are relatively few related structures having a similar substitution pattern to the tetra-substituted pyrrolidine ring of (I). The chemical diagrams for the two most closely related structures, (III), which has two hydroxyl substituents rather than acetyloxy (ALAVOA; Qian et al., 2016), and (IV), which has more complex substituents (RAJDUC; Coleman et al., 2004), are shown in Fig. 9.

\section{Synthesis and crystallization}

To a solution of 4-nitrobenzyl $(2 S, 3 S, 4 R)$-3,4-dihydroxy-2(4-methoxyphenyl)pyrrolidine-1-carboxylate (602 mg,
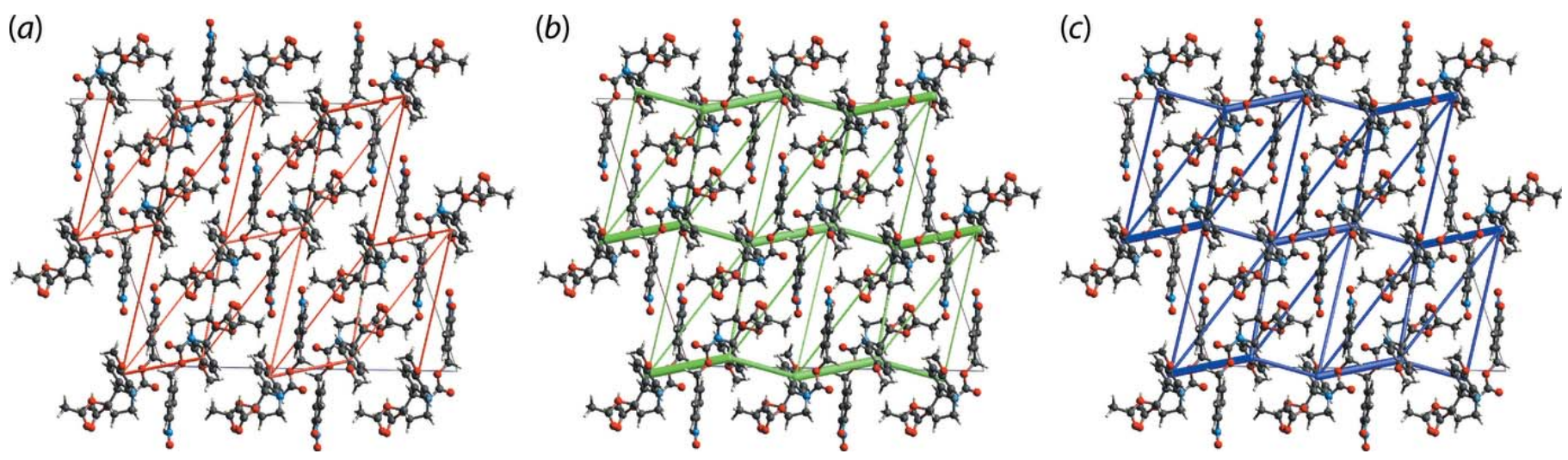

Figure 8

Perspective views of the energy frameworks calculated for (I) and viewed down the $b$ axis showing $(a)$ electrostatic potential force, $(b)$ dispersion force and $(c)$ total energy. The radii of the cylinders are proportional to the relative magnitudes of the corresponding energies and were adjusted to the same scale factor of 50 with a cut-off value of $5 \mathrm{~kJ} \mathrm{~mol}^{-1}$ within $1 \times 1 \times 1$ unit cells. 
<smiles>O=C(OCc1ccccc1)N1CC(O)C(O)C1C(O)CO</smiles>

(III)<smiles>CCC(c1cc(OC)c(C)c(OC)c1OCOC)C1C(OCc2cc([N+](=O)[O-])cc([N+](=O)[O-])c2)C(OCc2cc([N+](=O)[O-])cc([N+](=O)[O-])c2)CN1C(=O)OC(C)(C)C</smiles>

(IV)

Figure 9

Chemical diagrams for (III) and (IV).

$1.55 \mathrm{mmol})$ in $\mathrm{CH}_{2} \mathrm{Cl}_{2}(15 \mathrm{ml})$ were added pyridine $(0.80 \mathrm{ml}$, $18.584 \mathrm{mmol})$, acetic anhydride $(3.00 \mathrm{ml}, 31.8 \mathrm{mmol})$ and $N, N$ dimethyl-4-aminopyridine $(2.00 \mathrm{mg}, 0.0164 \mathrm{mmol})$. The solution was stirred for $2 \mathrm{~h}$ at room temperature, concentrated in a rota-evaporator and the residue dissolved in EtOAc $(10 \mathrm{ml})$. The resulting solution was washed with a $\mathrm{HCl} 5 \%$ solution $(3 \times 5 \mathrm{ml})$ and with saturated solutions of $\mathrm{NaHCO}_{3}(2 \times 5 \mathrm{ml})$ and of $\mathrm{NaCl}(5 \mathrm{ml})$. The phases were separated and the organic phase was dried with anhydrous $\mathrm{Na}_{2} \mathrm{SO}_{4}$, filtered and concentrated in vacuo.

The residue was purified by flash column chromatography in silica gel, using an EtOAc/n-hexane elution gradient (1:3 and 1:2). Yield: $716 \mathrm{mg}$ (98\%). Colourless irregular crystals for the $\mathrm{X}$-ray analysis were obtained by the slow evaporation of its $n$-hexane solution. M.p. $409.5-410.5 \mathrm{~K}$. The ${ }^{1} \mathrm{H}$ and ${ }^{13} \mathrm{C}\left\{{ }^{1} \mathrm{H}\right\}$ NMR reflect the presence of two conformational rotamers in solution. ${ }^{1} \mathrm{H}$ NMR $\left(500 \mathrm{MHz}, \mathrm{C}_{6} \mathrm{D}_{6}\right): \delta=7.75(d, J=7.3 \mathrm{~Hz}$, $0.4 \mathrm{H}) ; 7.65(d, J=7.9 \mathrm{~Hz}, 1.2 \mathrm{H}) ; 7.18(m, 1.9 \mathrm{H}) ; 6.99(d, J=$ $7.9 \mathrm{~Hz}, 1.1 \mathrm{H}) ; 6.76(d, J=7.0 \mathrm{~Hz}, 0.5 \mathrm{H}) ; 6.72(d, J=7.3 \mathrm{~Hz}$, $0.6 \mathrm{H}) ; 6.65(d, J=7.9 \mathrm{~Hz}, 1.3 \mathrm{H}) ; 6.37(d, J=9.3 \mathrm{~Hz}, 1 \mathrm{H}) ; 5.42$ $(s, 0.2 \mathrm{H}) ; 5.33(m, 1.9 \mathrm{H}) ; 5.00(s, 0.5 \mathrm{H}) ; 4.92(d, J=13.7 \mathrm{~Hz}$, $0.6 \mathrm{H}) ; 4.74(s, 0.6 \mathrm{H}) ; 4.44(d, J=13.7 \mathrm{~Hz}, 0.6 \mathrm{H}) ; 3.89(m, 1.8 \mathrm{H})$; $3.72(s, 0.3 \mathrm{H}) ; 3.29(s, 3 \mathrm{H}) ; 3.35-3.23(m, 0.3 \mathrm{H}) ; 1.61-1.60(2 s$, $6 \mathrm{H}) .{ }^{1} \mathrm{H} \mathrm{NMR}\left(500 \mathrm{MHz}, \mathrm{CDCl}_{3}\right.$, TMS r.t.): $\delta=8.23(d, J=$ $8.2 \mathrm{~Hz}, 0.6 \mathrm{H}) ; 8.00(d, J=8.2 \mathrm{~Hz}, 1.2 \mathrm{H}) ; 7.53(d, J=7.9 \mathrm{~Hz}$, $0.7 \mathrm{H}) ; 7.16(m, 2 \mathrm{H}) ; 6.96(d, J=8.5 \mathrm{~Hz}, 1.2 \mathrm{H}) ; 6.88(d, J=$ $8.5 \mathrm{~Hz}, 2.0 \mathrm{H})$; 5.45-5.32 ( $m, 1 \mathrm{H})$; 5.31-5.18 ( $m, 2.3 \mathrm{H})$; 5.01$4.87(m, 1.6 \mathrm{H}) ; 4.13(m, 0.3 \mathrm{H}) ; 4.06(d d, J=11.6 \mathrm{~Hz}$ and $6.4 \mathrm{~Hz}$, $0.7 \mathrm{H}) ; 3.85-3.67(s+m, 4.1 \mathrm{H}) ; 2.12-2.07(4 s, 6 \mathrm{H}) .{ }^{13} \mathrm{C}\left\{{ }^{1} \mathrm{H}\right\}$ NMR (125 MHz, $\mathrm{CDCl}_{3}$, r.t.): $\delta=169.9 ; 169.8 ; 159.4 ; 159.2$; $154.2 ; 154.1 ; 147.6 ; 147.2 ; 143.6 ; 143.4 ; 130.6 ; 129.4 ; 128.1 ; 127.5$; $126.8 ; 126.7 ; 123.7 ; 123.4 ; 114.2 ; 78.2 ; 69.2 ; 68.7 ; 65.7 ; 65.5 ; 64.7$; $64.1 ; 55.3 ; 55.2 ; 49.0 ; 48.4 ; 20.8 ; 20.7 ; 20.6$.
Table 5

Experimental details.

\begin{tabular}{|c|c|}
\hline \multicolumn{2}{|l|}{ Crystal data } \\
\hline Chemical formula & $\mathrm{C}_{23} \mathrm{H}_{24} \mathrm{~N}_{2} \mathrm{O}_{9}$ \\
\hline$M_{\mathrm{r}}$ & 472.44 \\
\hline Crystal system, space group & Monoclinic, $C 2 / c$ \\
\hline Temperature $(\mathrm{K})$ & 293 \\
\hline$a, b, c(\AA)$ & $23.6396(5), 8.2906(2), 24.7683(5)$ \\
\hline$\beta\left(^{\circ}\right)$ & $110.013(1)$ \\
\hline$V\left(\AA^{3}\right)$ & $4561.13(18)$ \\
\hline$Z$ & 8 \\
\hline Radiation type & Мо $K \alpha$ \\
\hline$\mu\left(\mathrm{mm}^{-1}\right)$ & 0.11 \\
\hline Crystal size (mm) & $0.40 \times 0.36 \times 0.18$ \\
\hline \multicolumn{2}{|l|}{ Data collection } \\
\hline Diffractometer & Enraf-Nonius TurboCAD-4 \\
\hline Absorption correction & $\begin{array}{l}\text { Multi-scan (SADABS; Sheldrick, } \\
\text { 1996) }\end{array}$ \\
\hline$T_{\min }, T_{\max }$ & $0.686,0.745$ \\
\hline $\begin{array}{l}\text { No. of measured, independent and } \\
\text { observed }[I>2 \sigma(I)] \text { reflections }\end{array}$ & $22357,4172,3646$ \\
\hline$R_{\text {int }}$ & 0.020 \\
\hline$(\sin \theta / \lambda)_{\max }\left(\AA^{-1}\right)$ & 0.603 \\
\hline \multicolumn{2}{|l|}{ Refinement } \\
\hline$R\left[F^{2}>2 \sigma\left(F^{2}\right)\right], w R\left(F^{2}\right), S$ & $0.041,0.112,1.01$ \\
\hline No. of reflections & 4172 \\
\hline No. of parameters & 310 \\
\hline $\mathrm{H}$-atom treatment & $\mathrm{H}$-atom parameters constrained \\
\hline$\Delta \rho_{\max }, \Delta \rho_{\min }\left(\mathrm{e} \AA^{-3}\right)$ & $0.30,-0.22$ \\
\hline
\end{tabular}

Computer programs: CAD-4 EXPRESS (Enraf-Nonius, 1989), XCAD4 (Harms \& Wocadlo, 1995), SIR2014 (Burla et al., 2015), SHELXL2018/3 (Sheldrick, 2015), ORTEP 3 for Windows (Farrugia, 2012), MarvinSketch (ChemAxon, 2010), DIAMOND (Brandenburg, 2006) and publCIF (Westrip, 2010).

\section{Refinement details}

Crystal data, data collection and structure refinement details are summarized in Table 5. The carbon-bound $\mathrm{H}$ atoms were placed in calculated positions $(\mathrm{C}-\mathrm{H}=0.93-0.98 \AA)$ and were included in the refinement in the riding model approximation, with $U_{\text {iso }}(\mathrm{H})$ set to $1.2-1.5 U_{\text {eq }}(\mathrm{C})$.

\section{Funding information}

The Brazilian agencies Coordination for the Improvement of Higher Education Personnel, CAPES, Finance Code 001 and the National Council for Scientific and Technological Development (CNPq) are acknowledged for grant Nos. 312210/ 2019-1, 433957/2018-2 and 406273/2015-4 to IC, for a fellowship 303207/2017-5 to JZS and a scholarship to SDP. Sunway University Sdn Bhd is also thanked for funding (grant No. STR-RCTR-RCCM-001-2019).

\section{References}

Brandenburg, K. (2006). DIAMOND. Crystal Impact GbR, Bonn, Germany.

Burla, M. C., Caliandro, R., Carrozzini, B., Cascarano, G. L., Cuocci, C., Giacovazzo, C., Mallamo, M., Mazzone, A. \& Polidori, G. (2015). J. Appl. Cryst. 48, 306-309.

ChemAxon (2010). Marvinsketch. http://www.chemaxon.com.

Coleman, R. S., Felpin, F.-X. \& Chen, W. (2004). J. Org. Chem. 69, 7309-7316. 
Contreras-García, J., Johnson, E. R., Keinan, S., Chaudret, R., Piquemal, J.-P., Beratan, D. N. \& Yang, W. (2011). J. Chem. Theory Comput. 7, 625-632.

Dallasta Pedroso, S., Caracelli, I., Zukerman-Schpector, J., SotoMonsalve, M., De Almeida Santos, R. H., Correia, C. R. D., Llanes Garcia, A. L., Kwong, H. C. \& Tiekink, E. R. T. (2020). Acta Cryst. E76, 967-972.

Dhameja, M. \& Gupta, P. (2019). Eur. J. Med. Chem. 176, article No. $343 \mathrm{e} 377$.

Enraf-Nonius (1989). CAD-4 EXPRESS. Enraf-Nonius, Delft, The Netherlands.

Farrugia, L. J. (2012). J. Appl. Cryst. 45, 849-854.

Garcia, A. L. L. (2008). PhD thesis, Universidade Estadual de Campinas, UNICAMP, Campinas, SP, Brazil.

Harms, K. \& Wocadlo, S. (1995). XCAD4. University of Marburg, Germany.

Johnson, E. R., Keinan, S., Mori-Sánchez, P., Contreras-García, J., Cohen, A. J. \& Yang, W. (2010). J. Am. Chem. Soc. 132, 64986506.
Kiappes, J. L., Hill, M. L., Alonzi, D. S., Miller, J. L., Iwaki, R., Sayce, A. C., Caputo, A. T., Kato, A. \& Zitzmann, N. (2018). Chem. Biol. 13, 60-65.

Qian, B.-C., Kamori, A., Kinami, K., Kato, A., Li, Y.-X., Fleet, G. W. J. \& Yu, C.-Y. (2016). Org. Biomol. Chem. 14, 4488-4498.

Sheldrick, G. M. (1996). SADABS. University of Göttingen, Germany.

Sheldrick, G. M. (2015). Acta Cryst. C71, 3-8.

Spek, A. L. (2020). Acta Cryst. E76, 1-11.

Tan, S. L., Jotani, M. M. \& Tiekink, E. R. T. (2019). Acta Cryst. E75, 308-318.

Taylor, C. M. \& Weir, C. A. (2000). J. Org. Chem. 65, 1414-1421.

Turner, M. J., Mckinnon, J. J., Wolff, S. K., Grimwood, D. J., Spackman, P. R., Jayatilaka, D. \& Spackman, M. A. (2017). Crystal Explorer 17. The University of Western Australia.

Westrip, S. P. (2010). J. Appl. Cryst. 43, 920-925.

Zukerman-Schpector, J., Sugiyama, F. H., Garcia, A. L. L., Correia, C. R. D., Jotani, M. M. \& Tiekink, E. R. T. (2017). Acta Cryst. E73, 1218-1222. 


\section{supporting information}

Acta Cryst. (2020). E76, 1080-1086 [https://doi.org/10.1107/S2056989020007914]

\section{4-Nitrobenzyl 3,4-bis(acetyloxy)-2-(4-methoxyphenyl)pyrrolidine-1-carboxyl-} ate: crystal structure, Hirshfeld surface analysis and computational chemistry

Sofia Dallasta Pedroso, Ignez Caracelli, Julio Zukerman-Schpector, Monica Soto-Monsalve, Regina H. De Almeida Santos, Carlos Roque D. Correia, Ariel L. Llanes Garcia, Huey Chong Kwong and Edward R. T. Tiekink

Computing details

Data collection: CAD-4 EXPRESS (Enraf-Nonius, 1989); cell refinement: CAD-4 EXPRESS (Enraf-Nonius, 1989); data reduction: XCAD4 (Harms \& Wocadlo, 1995); program(s) used to solve structure: SIR2014 (Burla et al., 2015); program(s) used to refine structure: SHELXL2018/3 (Sheldrick, 2015); molecular graphics: ORTEP-3 for Windows (Farrugia, 2012), MarvinSketch (ChemAxon, 2010) and DIAMOND (Brandenburg, 2006); software used to prepare material for publication: publCIF (Westrip, 2010).

4-Nitrobenzyl 3,4-bis(acetyloxy)-2-(4-methoxyphenyl)pyrrolidine-1-carboxylate

Crystal data

$\mathrm{C}_{23} \mathrm{H}_{24} \mathrm{~N}_{2} \mathrm{O}_{9}$

$M_{r}=472.44$

Monoclinic, $C 2 / c$

$a=23.6396(5) \AA$

$b=8.2906(2) \AA$

$c=24.7683(5) \AA$

$\beta=110.013(1)^{\circ}$

$V=4561.13(18) \AA^{3}$

$Z=8$

Data collection

Enraf-Nonius TurboCAD-4 diffractometer

Radiation source: Enraf-Nonius FR590

non-profiled $\omega / 2 \theta$ scans

Absorption correction: multi-scan

(SADABS; Sheldrick, 1996)

$T_{\min }=0.686, T_{\max }=0.745$

22357 measured reflections

4172 independent reflections
$F(000)=1984$

$D_{\mathrm{x}}=1.376 \mathrm{Mg} \mathrm{m}^{-3}$

Mo $K \alpha$ radiation, $\lambda=0.71073 \AA$

Cell parameters from 9984 reflections

$\theta=2.6-25.4^{\circ}$

$\mu=0.11 \mathrm{~mm}^{-1}$

$T=293 \mathrm{~K}$

Irregular, colourless

$0.40 \times 0.36 \times 0.18 \mathrm{~mm}$

3646 reflections with $I>2 \sigma(I)$

$R_{\text {int }}=0.020$

$\theta_{\max }=25.4^{\circ}, \theta_{\min }=1.8^{\circ}$

$h=-28 \rightarrow 28$

$k=-7 \rightarrow 10$

$l=-29 \rightarrow 29$

3 standard reflections every $120 \mathrm{~min}$

intensity decay: $2 \%$ 


\section{Refinement}

Refinement on $F^{2}$

Least-squares matrix: full

$R\left[F^{2}>2 \sigma\left(F^{2}\right)\right]=0.041$

$w R\left(F^{2}\right)=0.112$

$S=1.01$

4172 reflections

310 parameters

0 restraints

Primary atom site location: structure-invariant direct methods
Secondary atom site location: difference Fourier map

Hydrogen site location: inferred from neighbouring sites

$\mathrm{H}$-atom parameters constrained

$w=1 /\left[\sigma^{2}\left(F_{\mathrm{o}}^{2}\right)+(0.0475 P)^{2}+5.1476 P\right]$ where $P=\left(F_{\mathrm{o}}{ }^{2}+2 F_{\mathrm{c}}{ }^{2}\right) / 3$

$(\Delta / \sigma)_{\max }=0.001$

$\Delta \rho_{\max }=0.30 \mathrm{e} \AA^{-3}$

$\Delta \rho_{\min }=-0.22$ e $\AA^{-3}$

Special details

Geometry. All esds (except the esd in the dihedral angle between two 1.s. planes) are estimated using the full covariance matrix. The cell esds are taken into account individually in the estimation of esds in distances, angles and torsion angles; correlations between esds in cell parameters are only used when they are defined by crystal symmetry. An approximate (isotropic) treatment of cell esds is used for estimating esds involving 1.s. planes.

Fractional atomic coordinates and isotropic or equivalent isotropic displacement parameters $\left(\AA^{2}\right)$

\begin{tabular}{|c|c|c|c|c|}
\hline & $x$ & $y$ & $z$ & $U_{\text {iso }} * / U_{\text {eq }}$ \\
\hline $\mathrm{C} 1$ & $0.41109(7)$ & $0.33440(18)$ & $0.82213(6)$ & $0.0313(3)$ \\
\hline $\mathrm{H} 1$ & 0.439778 & 0.265045 & 0.812398 & $0.038^{*}$ \\
\hline $\mathrm{C} 2$ & $0.35064(7)$ & 0.33405 (19) & $0.77230(7)$ & $0.0336(4)$ \\
\hline $\mathrm{H} 2$ & 0.327740 & 0.430457 & 0.774943 & $0.040 *$ \\
\hline $\mathrm{C} 3$ & $0.31777(7)$ & $0.1856(2)$ & $0.78170(7)$ & $0.0378(4)$ \\
\hline $\mathrm{H} 3$ & 0.274273 & 0.192051 & 0.761254 & $0.045^{*}$ \\
\hline $\mathrm{C} 4$ & $0.33330(7)$ & $0.1864(2)$ & $0.84615(7)$ & $0.0403(4)$ \\
\hline $\mathrm{H} 4 \mathrm{~A}$ & 0.304809 & 0.251133 & 0.857137 & $0.048 *$ \\
\hline $\mathrm{H} 4 \mathrm{~B}$ & 0.333567 & 0.077780 & 0.860767 & $0.048^{*}$ \\
\hline $\mathrm{C} 5$ & $0.43296(7)$ & $0.20974(18)$ & $0.91863(7)$ & $0.0345(4)$ \\
\hline C6 & $0.53264(8)$ & $0.2143(2)$ & $0.98048(8)$ & $0.0528(5)$ \\
\hline H6A & 0.542252 & 0.103154 & 0.974917 & $0.063^{*}$ \\
\hline H6B & 0.516931 & 0.217441 & 1.011878 & $0.063 *$ \\
\hline $\mathrm{C} 7$ & $0.58827(8)$ & $0.3154(2)$ & $0.99508(7)$ & $0.0417(4)$ \\
\hline $\mathrm{C} 8$ & $0.64314(9)$ & $0.2417(3)$ & $1.02204(9)$ & $0.0565(5)$ \\
\hline $\mathrm{H} 8$ & 0.644787 & 0.130582 & 1.027501 & $0.068^{*}$ \\
\hline C9 & $0.69526(9)$ & $0.3306(3)$ & $1.04088(10)$ & $0.0645(6)$ \\
\hline H9 & 0.732107 & 0.280446 & 1.058971 & $0.077^{*}$ \\
\hline $\mathrm{C} 10$ & $0.69219(8)$ & 0.4939 (3) & $1.03263(8)$ & $0.0528(5)$ \\
\hline C11 & $0.63872(9)$ & $0.5713(3)$ & $1.00515(9)$ & $0.0544(5)$ \\
\hline H11 & 0.637581 & 0.682263 & 0.999450 & $0.065^{*}$ \\
\hline C12 & $0.58661(8)$ & $0.4804(2)$ & $0.98615(8)$ & $0.0494(5)$ \\
\hline H12 & 0.550017 & 0.530722 & 0.967144 & $0.059^{*}$ \\
\hline C13 & $0.43684(7)$ & $0.50197(18)$ & $0.83547(6)$ & $0.0316(3)$ \\
\hline C14 & $0.40971(7)$ & $0.6175(2)$ & $0.85901(7)$ & $0.0372(4)$ \\
\hline H14 & 0.376437 & 0.589579 & 0.868927 & $0.045^{*}$ \\
\hline C15 & $0.43136(8)$ & $0.7731(2)$ & $0.86789(8)$ & $0.0412(4)$ \\
\hline H15 & 0.412718 & 0.849067 & 0.883778 & $0.049 *$ \\
\hline
\end{tabular}




$\begin{array}{lllll}\text { C16 } & 0.48067(8) & 0.8167(2) & 0.85329(8) & 0.0438(4) \\ \text { C17 } & 0.50828(8) & 0.7033(2) & 0.83008(9) & 0.0513(5) \\ \text { H17 } & 0.541530 & 0.731489 & 0.820158 & 0.062^{*} \\ \text { C18 } & 0.48621(8) & 0.5466(2) & 0.82156(8) & 0.0430(4) \\ \text { H18 } & 0.505194 & 0.470334 & 0.806132 & 0.052^{*} \\ \text { C19 } & 0.54992(12) & 1.0247(3) & 0.85250(17) & 0.1022(11) \\ \text { H19A } & 0.583775 & 0.962689 & 0.875791 & 0.153^{*} \\ \text { H19B } & 0.557073 & 1.137012 & 0.861793 & 0.153^{*} \\ \text { H19C } & 0.544479 & 1.008448 & 0.812661 & 0.153^{*} \\ \text { C20 } & 0.31789(8) & 0.3956(2) & 0.67329(7) & 0.0412(4) \\ \text { C21 } & 0.33733(10) & 0.4076(3) & 0.62226(9) & 0.0641(6) \\ \text { H21A } & 0.341021 & 0.301250 & 0.608472 & 0.096^{*} \\ \text { H21B } & 0.375514 & 0.461491 & 0.632865 & 0.096^{*} \\ \text { H21C } & 0.307975 & 0.467627 & 0.592548 & 0.096^{*} \\ \text { C22 } & 0.31168(8) & -0.0347(2) & 0.71859(8) & 0.0416(4) \\ \text { C23 } & 0.34279(10) & -0.1848(2) & 0.71099(9) & 0.0565(5) \\ \text { H23A } & 0.329284 & -0.273887 & 0.728173 & 0.085^{*} \\ \text { H23B } & 0.385482 & -0.171936 & 0.729165 & 0.085^{*} \\ \text { H23C } & 0.333649 & -0.205264 & 0.670751 & 0.085^{*} \\ \text { N1 } & 0.39393(6) & 0.25809(16) & 0.86773(6) & 0.0352(3) \\ \text { N2 } & 0.74834(9) & 0.5888(3) & 1.05360(8) & 0.0727(6) \\ \text { O1 } & 0.41991(6) & 0.12222(15) & 0.95189(5) & 0.0462(3) \\ \text { O2 } & 0.48803(5) & 0.27396(14) & 0.92893(5) & 0.0394(3) \\ \text { O3 } & 0.79605(8) & 0.5171(3) & 1.06567(10) & 0.1097(8) \\ \text { O4 } & 0.74408(9) & 0.7331(3) & 1.05857(8) & 0.0893(6) \\ \text { O5 } & 0.49776(7) & 0.97485(16) & 0.86316(8) & 0.0654(4) \\ \text { O6 } & 0.36272(5) & 0.33834(15) & 0.71959(5) & 0.0410(3) \\ \text { O7 } & 0.26983(6) & 0.4321(2) & 0.67504(6) & 0.0632(4) \\ \text { O8 } & 0.34399(5) & 0.04280(14) & 0.76655(5) & 0.0441(3) \\ \text { O9 } & 0.26372(7) & 0.0104(2) & 0.68714(6) & 0.0684(5)\end{array}$

Atomic displacement parameters $\left(\AA^{2}\right)$

\begin{tabular}{lllllll}
\hline & $U^{11}$ & $U^{22}$ & $U^{33}$ & $U^{12}$ & $U^{13}$ & $U^{23}$ \\
\hline C1 & $0.0301(8)$ & $0.0308(8)$ & $0.0299(8)$ & $0.0021(6)$ & $0.0061(6)$ & $0.0014(6)$ \\
C2 & $0.0311(8)$ & $0.0356(8)$ & $0.0303(8)$ & $0.0036(6)$ & $0.0057(6)$ & $-0.0026(6)$ \\
C3 & $0.0270(8)$ & $0.0371(9)$ & $0.0431(9)$ & $0.0004(6)$ & $0.0039(7)$ & $-0.0050(7)$ \\
C4 & $0.0319(8)$ & $0.0426(9)$ & $0.0435(9)$ & $-0.0059(7)$ & $0.0091(7)$ & $0.0002(7)$ \\
C5 & $0.0390(9)$ & $0.0266(7)$ & $0.0342(8)$ & $0.0002(6)$ & $0.0075(7)$ & $0.0010(7)$ \\
C6 & $0.0460(10)$ & $0.0521(11)$ & $0.0440(10)$ & $-0.0034(9)$ & $-0.0057(8)$ & $0.0169(9)$ \\
C7 & $0.0402(9)$ & $0.0491(10)$ & $0.0295(8)$ & $-0.0012(8)$ & $0.0037(7)$ & $0.0018(7)$ \\
C8 & $0.0469(11)$ & $0.0589(12)$ & $0.0545(12)$ & $0.0051(9)$ & $0.0055(9)$ & $0.0106(10)$ \\
C9 & $0.0381(10)$ & $0.0846(17)$ & $0.0617(13)$ & $0.0065(10)$ & $0.0053(9)$ & $0.0104(12)$ \\
C10 & $0.0394(10)$ & $0.0797(15)$ & $0.0384(10)$ & $-0.0140(10)$ & $0.0121(8)$ & $-0.0139(10)$ \\
C11 & $0.0595(12)$ & $0.0502(11)$ & $0.0546(12)$ & $-0.0096(9)$ & $0.0207(10)$ & $-0.0123(9)$ \\
C12 & $0.0407(10)$ & $0.0497(11)$ & $0.0518(11)$ & $0.0012(8)$ & $0.0082(8)$ & $-0.0019(9)$ \\
C13 & $0.0315(8)$ & $0.0317(8)$ & $0.0264(7)$ & $-0.0002(6)$ & $0.0032(6)$ & $0.0023(6)$ \\
C14 & $0.0380(9)$ & $0.0376(9)$ & $0.0369(9)$ & $-0.0017(7)$ & $0.0140(7)$ & $0.0002(7)$
\end{tabular}




\begin{tabular}{lllllll}
$\mathrm{C} 15$ & $0.0452(10)$ & $0.0365(9)$ & $0.0411(9)$ & $0.0006(7)$ & $0.0139(8)$ & $-0.0052(7)$ \\
$\mathrm{C} 16$ & $0.0407(9)$ & $0.0327(9)$ & $0.0521(11)$ & $-0.0051(7)$ & $0.0085(8)$ & $-0.0015(8)$ \\
$\mathrm{C} 17$ & $0.0409(10)$ & $0.0440(10)$ & $0.0746(14)$ & $-0.0085(8)$ & $0.0269(10)$ & $-0.0028(9)$ \\
$\mathrm{C} 18$ & $0.0395(9)$ & $0.0381(9)$ & $0.0541(11)$ & $0.0003(7)$ & $0.0195(8)$ & $-0.0042(8)$ \\
$\mathrm{C} 19$ & $0.0737(17)$ & $0.0508(14)$ & $0.194(4)$ & $-0.0262(13)$ & $0.061(2)$ & $-0.0194(18)$ \\
C20 & $0.0432(10)$ & $0.0369(9)$ & $0.0345(9)$ & $0.0017(7)$ & $0.0017(7)$ & $-0.0005(7)$ \\
C21 & $0.0683(14)$ & $0.0829(16)$ & $0.0367(10)$ & $-0.0014(12)$ & $0.0123(10)$ & $0.0033(10)$ \\
C22 & $0.0423(10)$ & $0.0399(9)$ & $0.0401(9)$ & $-0.0079(7)$ & $0.0110(8)$ & $-0.0029(7)$ \\
C23 & $0.0630(13)$ & $0.0459(11)$ & $0.0595(13)$ & $-0.0002(9)$ & $0.0196(10)$ & $-0.0112(9)$ \\
N1 & $0.0330(7)$ & $0.0341(7)$ & $0.0328(7)$ & $-0.0050(6)$ & $0.0042(6)$ & $0.0035(6)$ \\
N2 & $0.0582(12)$ & $0.1074(18)$ & $0.0531(11)$ & $-0.0282(12)$ & $0.0200(9)$ & $-0.0212(11)$ \\
O1 & $0.0504(7)$ & $0.0427(7)$ & $0.0422(7)$ & $-0.0020(6)$ & $0.0116(6)$ & $0.0132(6)$ \\
O2 & $0.0364(6)$ & $0.0372(6)$ & $0.0338(6)$ & $-0.0042(5)$ & $-0.0019(5)$ & $0.0075(5)$ \\
O3 & $0.0421(10)$ & $0.154(2)$ & $0.1255(18)$ & $-0.0190(12)$ & $0.0188(10)$ & $-0.0200(15)$ \\
O4 & $0.0919(13)$ & $0.1010(15)$ & $0.0811(13)$ & $-0.0485(12)$ & $0.0372(11)$ & $-0.0322(11)$ \\
O5 & $0.0564(8)$ & $0.0360(7)$ & $0.1062(13)$ & $-0.0139(6)$ & $0.0308(8)$ & $-0.0144(7)$ \\
O6 & $0.0363(6)$ & $0.0518(7)$ & $0.0304(6)$ & $0.0068(5)$ & $0.0058(5)$ & $-0.0001(5)$ \\
O7 & $0.0482(8)$ & $0.0815(11)$ & $0.0506(8)$ & $0.0230(7)$ & $0.0050(6)$ & $0.0112(7)$ \\
O8 & $0.0352(6)$ & $0.0376(6)$ & $0.0502(7)$ & $0.0009(5)$ & $0.0024(5)$ & $-0.0093(5)$ \\
O9 & $0.0561(9)$ & $0.0722(10)$ & $0.0559(9)$ & $0.0083(8)$ & $-0.0077(7)$ & $-0.0200(8)$ \\
& & & & & & \\
\hline
\end{tabular}

Geometric parameters $\left(\AA,{ }^{\circ}\right)$

\begin{tabular}{llll}
\hline $\mathrm{C} 1-\mathrm{N} 1$ & $1.468(2)$ & $\mathrm{C} 12-\mathrm{H} 12$ & 0.9300 \\
$\mathrm{C} 1-\mathrm{C} 13$ & $1.507(2)$ & $\mathrm{C} 13-\mathrm{C} 18$ & $1.376(2)$ \\
$\mathrm{C} 1-\mathrm{C} 2$ & $1.536(2)$ & $\mathrm{C} 13-\mathrm{C} 14$ & $1.388(2)$ \\
$\mathrm{C} 1-\mathrm{H} 1$ & 0.9800 & $\mathrm{C} 14-\mathrm{C} 15$ & $1.377(2)$ \\
$\mathrm{C} 2-\mathrm{O} 6$ & $1.4293(19)$ & $\mathrm{C} 14-\mathrm{H} 14$ & 0.9300 \\
$\mathrm{C} 2-\mathrm{C} 3$ & $1.516(2)$ & $\mathrm{C} 15-\mathrm{C} 16$ & $1.381(3)$ \\
$\mathrm{C} 2-\mathrm{H} 2$ & 0.9800 & $\mathrm{C} 15-\mathrm{H} 15$ & 0.9300 \\
$\mathrm{C} 3-\mathrm{O} 8$ & $1.444(2)$ & $\mathrm{C} 16-\mathrm{O} 5$ & $1.369(2)$ \\
$\mathrm{C} 3-\mathrm{C} 4$ & $1.511(2)$ & $\mathrm{C} 16-\mathrm{C} 17$ & $1.378(3)$ \\
$\mathrm{C} 3-\mathrm{H} 3$ & 0.9800 & $\mathrm{C} 17-\mathrm{C} 18$ & $1.388(3)$ \\
$\mathrm{C} 4-\mathrm{N} 1$ & $1.472(2)$ & $\mathrm{C} 17-\mathrm{H} 17$ & 0.9300 \\
$\mathrm{C} 4-\mathrm{H} 4 \mathrm{~A}$ & 0.9700 & $\mathrm{C} 18-\mathrm{H} 18$ & 0.9300 \\
$\mathrm{C} 4-\mathrm{H} 4 \mathrm{~B}$ & 0.9700 & $\mathrm{C} 19-\mathrm{O} 5$ & $1.409(3)$ \\
$\mathrm{C} 5-\mathrm{O} 1$ & $1.214(2)$ & $\mathrm{C} 19-\mathrm{H} 19 \mathrm{~A}$ & 0.9600 \\
$\mathrm{C} 5-\mathrm{N} 1$ & $1.344(2)$ & $\mathrm{C} 19-\mathrm{H} 19 \mathrm{~B}$ & 0.9600 \\
$\mathrm{C} 5-\mathrm{O} 2$ & $1.3476(19)$ & $\mathrm{C} 19-\mathrm{H} 19 \mathrm{C}$ & 0.9600 \\
$\mathrm{C} 6-\mathrm{O} 2$ & $1.4371(19)$ & $\mathrm{C} 20-\mathrm{O} 7$ & $1.191(2)$ \\
$\mathrm{C} 6-\mathrm{C} 7$ & $1.496(3)$ & $\mathrm{C} 20-\mathrm{O} 6$ & $1.354(2)$ \\
$\mathrm{C} 6-\mathrm{H} 6 \mathrm{~A}$ & 0.9700 & $\mathrm{C} 20-\mathrm{C} 21$ & $1.488(3)$ \\
$\mathrm{C} 6-\mathrm{H} 6 \mathrm{~B}$ & 0.9700 & $\mathrm{C} 21-\mathrm{H} 21 \mathrm{~A}$ & 0.9600 \\
$\mathrm{C} 7-\mathrm{C} 8$ & $1.382(3)$ & $\mathrm{C} 21-\mathrm{H} 21 \mathrm{~B}$ & 0.9600 \\
$\mathrm{C} 7-\mathrm{C} 12$ & $1.385(3)$ & $\mathrm{C} 21-\mathrm{H} 21 \mathrm{C}$ & 0.9600 \\
$\mathrm{C} 8-\mathrm{C} 9$ & $1.373(3)$ & $\mathrm{C} 22-\mathrm{O} 9$ & $1.195(2)$ \\
$\mathrm{C} 8-\mathrm{H} 8$ & 0.9300 & $\mathrm{C} 22-\mathrm{O} 8$ & $1.337(2)$ \\
$\mathrm{C} 9-\mathrm{C} 10$ & $1.368(3)$ & $\mathrm{C} 22-\mathrm{C} 23$ & $1.490(3)$ \\
& & &
\end{tabular}




\begin{tabular}{|c|c|c|c|}
\hline C9-H9 & 0.9300 & $\mathrm{C} 23-\mathrm{H} 23 \mathrm{~A}$ & 0.9600 \\
\hline $\mathrm{C} 10-\mathrm{C} 11$ & $1.372(3)$ & $\mathrm{C} 23-\mathrm{H} 23 \mathrm{~B}$ & 0.9600 \\
\hline $\mathrm{C} 10-\mathrm{N} 2$ & $1.476(3)$ & $\mathrm{C} 23-\mathrm{H} 23 \mathrm{C}$ & 0.9600 \\
\hline $\mathrm{C} 11-\mathrm{C} 12$ & $1.382(3)$ & $\mathrm{N} 2-\mathrm{O} 3$ & $1.218(3)$ \\
\hline $\mathrm{C} 11-\mathrm{H} 11$ & 0.9300 & $\mathrm{~N} 2-\mathrm{O} 4$ & $1.210(3)$ \\
\hline $\mathrm{N} 1-\mathrm{C} 1-\mathrm{C} 13$ & $115.20(13)$ & $\mathrm{C} 18-\mathrm{C} 13-\mathrm{C} 1$ & $120.44(15)$ \\
\hline $\mathrm{N} 1-\mathrm{C} 1-\mathrm{C} 2$ & $101.03(12)$ & $\mathrm{C} 14-\mathrm{C} 13-\mathrm{C} 1$ & $121.24(14)$ \\
\hline $\mathrm{C} 13-\mathrm{C} 1-\mathrm{C} 2$ & $111.89(12)$ & $\mathrm{C} 15-\mathrm{C} 14-\mathrm{C} 13$ & $120.91(16)$ \\
\hline $\mathrm{N} 1-\mathrm{C} 1-\mathrm{H} 1$ & 109.5 & $\mathrm{C} 15-\mathrm{C} 14-\mathrm{H} 14$ & 119.5 \\
\hline $\mathrm{C} 13-\mathrm{C} 1-\mathrm{H} 1$ & 109.5 & $\mathrm{C} 13-\mathrm{C} 14-\mathrm{H} 14$ & 119.5 \\
\hline $\mathrm{C} 2-\mathrm{C} 1-\mathrm{H} 1$ & 109.5 & $\mathrm{C} 14-\mathrm{C} 15-\mathrm{C} 16$ & $120.28(16)$ \\
\hline $\mathrm{O} 6-\mathrm{C} 2-\mathrm{C} 3$ & $115.70(13)$ & $\mathrm{C} 14-\mathrm{C} 15-\mathrm{H} 15$ & 119.9 \\
\hline $\mathrm{O} 6-\mathrm{C} 2-\mathrm{C} 1$ & $108.19(12)$ & $\mathrm{C} 16-\mathrm{C} 15-\mathrm{H} 15$ & 119.9 \\
\hline $\mathrm{C} 3-\mathrm{C} 2-\mathrm{C} 1$ & $105.25(13)$ & $\mathrm{O} 5-\mathrm{C} 16-\mathrm{C} 17$ & $125.10(17)$ \\
\hline $\mathrm{O} 6-\mathrm{C} 2-\mathrm{H} 2$ & 109.2 & $\mathrm{O} 5-\mathrm{C} 16-\mathrm{C} 15$ & $115.33(17)$ \\
\hline $\mathrm{C} 3-\mathrm{C} 2-\mathrm{H} 2$ & 109.2 & $\mathrm{C} 17-\mathrm{C} 16-\mathrm{C} 15$ & $119.56(16)$ \\
\hline $\mathrm{C} 1-\mathrm{C} 2-\mathrm{H} 2$ & 109.2 & $\mathrm{C} 16-\mathrm{C} 17-\mathrm{C} 18$ & $119.65(17)$ \\
\hline $\mathrm{O} 8-\mathrm{C} 3-\mathrm{C} 4$ & $107.94(14)$ & $\mathrm{C} 16-\mathrm{C} 17-\mathrm{H} 17$ & 120.2 \\
\hline $\mathrm{O} 8-\mathrm{C} 3-\mathrm{C} 2$ & $109.73(13)$ & $\mathrm{C} 18-\mathrm{C} 17-\mathrm{H} 17$ & 120.2 \\
\hline $\mathrm{C} 4-\mathrm{C} 3-\mathrm{C} 2$ & $101.92(13)$ & $\mathrm{C} 13-\mathrm{C} 18-\mathrm{C} 17$ & $121.37(17)$ \\
\hline $\mathrm{O} 8-\mathrm{C} 3-\mathrm{H} 3$ & 112.2 & $\mathrm{C} 13-\mathrm{C} 18-\mathrm{H} 18$ & 119.3 \\
\hline $\mathrm{C} 4-\mathrm{C} 3-\mathrm{H} 3$ & 112.2 & $\mathrm{C} 17-\mathrm{C} 18-\mathrm{H} 18$ & 119.3 \\
\hline $\mathrm{C} 2-\mathrm{C} 3-\mathrm{H} 3$ & 112.2 & $\mathrm{O} 5-\mathrm{C} 19-\mathrm{H} 19 \mathrm{~A}$ & 109.5 \\
\hline $\mathrm{N} 1-\mathrm{C} 4-\mathrm{C} 3$ & $103.88(13)$ & $\mathrm{O} 5-\mathrm{C} 19-\mathrm{H} 19 \mathrm{~B}$ & 109.5 \\
\hline $\mathrm{N} 1-\mathrm{C} 4-\mathrm{H} 4 \mathrm{~A}$ & 111.0 & $\mathrm{H} 19 \mathrm{~A}-\mathrm{C} 19-\mathrm{H} 19 \mathrm{~B}$ & 109.5 \\
\hline $\mathrm{C} 3-\mathrm{C} 4-\mathrm{H} 4 \mathrm{~A}$ & 111.0 & $\mathrm{O} 5-\mathrm{C} 19-\mathrm{H} 19 \mathrm{C}$ & 109.5 \\
\hline $\mathrm{N} 1-\mathrm{C} 4-\mathrm{H} 4 \mathrm{~B}$ & 111.0 & $\mathrm{H} 19 \mathrm{~A}-\mathrm{C} 19-\mathrm{H} 19 \mathrm{C}$ & 109.5 \\
\hline $\mathrm{C} 3-\mathrm{C} 4-\mathrm{H} 4 \mathrm{~B}$ & 111.0 & $\mathrm{H} 19 \mathrm{~B}-\mathrm{C} 19-\mathrm{H} 19 \mathrm{C}$ & 109.5 \\
\hline $\mathrm{H} 4 \mathrm{~A}-\mathrm{C} 4-\mathrm{H} 4 \mathrm{~B}$ & 109.0 & $\mathrm{O} 7-\mathrm{C} 20-\mathrm{O} 6$ & $122.57(17)$ \\
\hline $\mathrm{O} 1-\mathrm{C} 5-\mathrm{N} 1$ & $124.23(15)$ & $\mathrm{O} 7-\mathrm{C} 20-\mathrm{C} 21$ & $126.14(17)$ \\
\hline $\mathrm{O} 1-\mathrm{C} 5-\mathrm{O} 2$ & $124.12(15)$ & $\mathrm{O} 6-\mathrm{C} 20-\mathrm{C} 21$ & $111.29(16)$ \\
\hline $\mathrm{N} 1-\mathrm{C} 5-\mathrm{O} 2$ & $111.62(14)$ & $\mathrm{C} 20-\mathrm{C} 21-\mathrm{H} 21 \mathrm{~A}$ & 109.5 \\
\hline $\mathrm{O} 2-\mathrm{C} 6-\mathrm{C} 7$ & $109.81(15)$ & $\mathrm{C} 20-\mathrm{C} 21-\mathrm{H} 21 \mathrm{~B}$ & 109.5 \\
\hline $\mathrm{O} 2-\mathrm{C} 6-\mathrm{H} 6 \mathrm{~A}$ & 109.7 & $\mathrm{H} 21 \mathrm{~A}-\mathrm{C} 21-\mathrm{H} 21 \mathrm{~B}$ & 109.5 \\
\hline $\mathrm{C} 7-\mathrm{C} 6-\mathrm{H} 6 \mathrm{~A}$ & 109.7 & $\mathrm{C} 20-\mathrm{C} 21-\mathrm{H} 21 \mathrm{C}$ & 109.5 \\
\hline $\mathrm{O} 2-\mathrm{C} 6-\mathrm{H} 6 \mathrm{~B}$ & 109.7 & $\mathrm{H} 21 \mathrm{~A}-\mathrm{C} 21-\mathrm{H} 21 \mathrm{C}$ & 109.5 \\
\hline $\mathrm{C} 7-\mathrm{C} 6-\mathrm{H} 6 \mathrm{~B}$ & 109.7 & $\mathrm{H} 21 \mathrm{~B}-\mathrm{C} 21-\mathrm{H} 21 \mathrm{C}$ & 109.5 \\
\hline $\mathrm{H} 6 \mathrm{~A}-\mathrm{C} 6-\mathrm{H} 6 \mathrm{~B}$ & 108.2 & $\mathrm{O} 9-\mathrm{C} 22-\mathrm{O} 8$ & $123.71(17)$ \\
\hline $\mathrm{C} 8-\mathrm{C} 7-\mathrm{C} 12$ & $119.00(18)$ & $\mathrm{O} 9-\mathrm{C} 22-\mathrm{C} 23$ & $125.35(17)$ \\
\hline $\mathrm{C} 8-\mathrm{C} 7-\mathrm{C} 6$ & $118.12(17)$ & $\mathrm{O} 8-\mathrm{C} 22-\mathrm{C} 23$ & $110.92(15)$ \\
\hline $\mathrm{C} 12-\mathrm{C} 7-\mathrm{C} 6$ & $122.73(17)$ & $\mathrm{C} 22-\mathrm{C} 23-\mathrm{H} 23 \mathrm{~A}$ & 109.5 \\
\hline $\mathrm{C} 9-\mathrm{C} 8-\mathrm{C} 7$ & $120.8(2)$ & $\mathrm{C} 22-\mathrm{C} 23-\mathrm{H} 23 \mathrm{~B}$ & 109.5 \\
\hline $\mathrm{C} 9-\mathrm{C} 8-\mathrm{H} 8$ & 119.6 & $\mathrm{H} 23 \mathrm{~A}-\mathrm{C} 23-\mathrm{H} 23 \mathrm{~B}$ & 109.5 \\
\hline $\mathrm{C} 7-\mathrm{C} 8-\mathrm{H} 8$ & 119.6 & $\mathrm{C} 22-\mathrm{C} 23-\mathrm{H} 23 \mathrm{C}$ & 109.5 \\
\hline $\mathrm{C} 10-\mathrm{C} 9-\mathrm{C} 8$ & $119.0(2)$ & $\mathrm{H} 23 \mathrm{~A}-\mathrm{C} 23-\mathrm{H} 23 \mathrm{C}$ & 109.5 \\
\hline $\mathrm{C} 10-\mathrm{C} 9-\mathrm{H} 9$ & 120.5 & $\mathrm{H} 23 \mathrm{~B}-\mathrm{C} 23-\mathrm{H} 23 \mathrm{C}$ & 109.5 \\
\hline $\mathrm{C} 8-\mathrm{C} 9-\mathrm{H} 9$ & 120.5 & $\mathrm{C} 5-\mathrm{N} 1-\mathrm{C} 1$ & $124.66(13)$ \\
\hline
\end{tabular}




\begin{tabular}{|c|c|c|c|}
\hline $\mathrm{C} 9-\mathrm{C} 10-\mathrm{C} 11$ & $121.97(19)$ & $\mathrm{C} 5-\mathrm{N} 1-\mathrm{C} 4$ & $119.39(14)$ \\
\hline $\mathrm{C} 9-\mathrm{C} 10-\mathrm{N} 2$ & $118.7(2)$ & $\mathrm{C} 1-\mathrm{N} 1-\mathrm{C} 4$ & $112.69(12)$ \\
\hline $\mathrm{C} 11-\mathrm{C} 10-\mathrm{N} 2$ & $119.3(2)$ & $\mathrm{O} 3-\mathrm{N} 2-\mathrm{O} 4$ & $124.1(2)$ \\
\hline $\mathrm{C} 10-\mathrm{C} 11-\mathrm{C} 12$ & $118.5(2)$ & $\mathrm{O} 3-\mathrm{N} 2-\mathrm{C} 10$ & $118.1(2)$ \\
\hline $\mathrm{C} 10-\mathrm{C} 11-\mathrm{H} 11$ & 120.8 & $\mathrm{O} 4-\mathrm{N} 2-\mathrm{C} 10$ & $117.8(2)$ \\
\hline $\mathrm{C} 12-\mathrm{C} 11-\mathrm{H} 11$ & 120.8 & $\mathrm{C} 5-\mathrm{O} 2-\mathrm{C} 6$ & $113.56(13)$ \\
\hline $\mathrm{C} 11-\mathrm{C} 12-\mathrm{C} 7$ & $120.73(18)$ & $\mathrm{C} 16-\mathrm{O} 5-\mathrm{C} 19$ & $118.13(17)$ \\
\hline $\mathrm{C} 11-\mathrm{C} 12-\mathrm{H} 12$ & 119.6 & $\mathrm{C} 20-\mathrm{O} 6-\mathrm{C} 2$ & $116.07(13)$ \\
\hline $\mathrm{C} 7-\mathrm{C} 12-\mathrm{H} 12$ & 119.6 & $\mathrm{C} 22-\mathrm{O} 8-\mathrm{C} 3$ & $117.36(13)$ \\
\hline $\mathrm{C} 18-\mathrm{C} 13-\mathrm{C} 14$ & $118.23(15)$ & & \\
\hline $\mathrm{N} 1-\mathrm{C} 1-\mathrm{C} 2-\mathrm{O} 6$ & $-155.47(12)$ & $\mathrm{C} 15-\mathrm{C} 16-\mathrm{C} 17-\mathrm{C} 18$ & $0.1(3)$ \\
\hline $\mathrm{C} 13-\mathrm{C} 1-\mathrm{C} 2-\mathrm{O} 6$ & $81.46(16)$ & $\mathrm{C} 14-\mathrm{C} 13-\mathrm{C} 18-\mathrm{C} 17$ & $-0.7(3)$ \\
\hline $\mathrm{N} 1-\mathrm{C} 1-\mathrm{C} 2-\mathrm{C} 3$ & $-31.22(15)$ & $\mathrm{C} 1-\mathrm{C} 13-\mathrm{C} 18-\mathrm{C} 17$ & $175.80(16)$ \\
\hline $\mathrm{C} 13-\mathrm{C} 1-\mathrm{C} 2-\mathrm{C} 3$ & $-154.29(13)$ & $\mathrm{C} 16-\mathrm{C} 17-\mathrm{C} 18-\mathrm{C} 13$ & $0.5(3)$ \\
\hline $\mathrm{O} 6-\mathrm{C} 2-\mathrm{C} 3-\mathrm{O} 8$ & $44.85(17)$ & $\mathrm{O} 1-\mathrm{C} 5-\mathrm{N} 1-\mathrm{C} 1$ & $-166.43(16)$ \\
\hline $\mathrm{C} 1-\mathrm{C} 2-\mathrm{C} 3-\mathrm{O} 8$ & $-74.51(15)$ & $\mathrm{O} 2-\mathrm{C} 5-\mathrm{N} 1-\mathrm{C} 1$ & $15.2(2)$ \\
\hline $\mathrm{O} 6-\mathrm{C} 2-\mathrm{C} 3-\mathrm{C} 4$ & $159.06(13)$ & $\mathrm{O} 1-\mathrm{C} 5-\mathrm{N} 1-\mathrm{C} 4$ & $-8.4(3)$ \\
\hline $\mathrm{C} 1-\mathrm{C} 2-\mathrm{C} 3-\mathrm{C} 4$ & $39.70(16)$ & $\mathrm{O} 2-\mathrm{C} 5-\mathrm{N} 1-\mathrm{C} 4$ & $173.30(14)$ \\
\hline $\mathrm{O} 8-\mathrm{C} 3-\mathrm{C} 4-\mathrm{N} 1$ & $83.80(15)$ & $\mathrm{C} 13-\mathrm{C} 1-\mathrm{N} 1-\mathrm{C} 5$ & $-68.82(19)$ \\
\hline $\mathrm{C} 2-\mathrm{C} 3-\mathrm{C} 4-\mathrm{N} 1$ & $-31.73(16)$ & $\mathrm{C} 2-\mathrm{C} 1-\mathrm{N} 1-\mathrm{C} 5$ & $170.43(14)$ \\
\hline $\mathrm{O} 2-\mathrm{C} 6-\mathrm{C} 7-\mathrm{C} 8$ & $-148.04(18)$ & $\mathrm{C} 13-\mathrm{C} 1-\mathrm{N} 1-\mathrm{C} 4$ & $131.85(14)$ \\
\hline $\mathrm{O} 2-\mathrm{C} 6-\mathrm{C} 7-\mathrm{C} 12$ & $36.3(3)$ & $\mathrm{C} 2-\mathrm{C} 1-\mathrm{N} 1-\mathrm{C} 4$ & $11.10(16)$ \\
\hline $\mathrm{C} 12-\mathrm{C} 7-\mathrm{C} 8-\mathrm{C} 9$ & $1.3(3)$ & $\mathrm{C} 3-\mathrm{C} 4-\mathrm{N} 1-\mathrm{C} 5$ & $-147.44(15)$ \\
\hline $\mathrm{C} 6-\mathrm{C} 7-\mathrm{C} 8-\mathrm{C} 9$ & $-174.4(2)$ & $\mathrm{C} 3-\mathrm{C} 4-\mathrm{N} 1-\mathrm{C} 1$ & $13.09(18)$ \\
\hline $\mathrm{C} 7-\mathrm{C} 8-\mathrm{C} 9-\mathrm{C} 10$ & $0.1(3)$ & $\mathrm{C} 9-\mathrm{C} 10-\mathrm{N} 2-\mathrm{O} 3$ & $16.0(3)$ \\
\hline $\mathrm{C} 8-\mathrm{C} 9-\mathrm{C} 10-\mathrm{C} 11$ & $-1.2(3)$ & $\mathrm{C} 11-\mathrm{C} 10-\mathrm{N} 2-\mathrm{O} 3$ & $-163.5(2)$ \\
\hline $\mathrm{C} 8-\mathrm{C} 9-\mathrm{C} 10-\mathrm{N} 2$ & $179.30(19)$ & $\mathrm{C} 9-\mathrm{C} 10-\mathrm{N} 2-\mathrm{O} 4$ & $-162.9(2)$ \\
\hline $\mathrm{C} 9-\mathrm{C} 10-\mathrm{C} 11-\mathrm{C} 12$ & $0.9(3)$ & $\mathrm{C} 11-\mathrm{C} 10-\mathrm{N} 2-\mathrm{O} 4$ & $17.7(3)$ \\
\hline $\mathrm{N} 2-\mathrm{C} 10-\mathrm{C} 11-\mathrm{C} 12$ & $-179.61(18)$ & $\mathrm{O} 1-\mathrm{C} 5-\mathrm{O} 2-\mathrm{C} 6$ & $7.0(2)$ \\
\hline $\mathrm{C} 10-\mathrm{C} 11-\mathrm{C} 12-\mathrm{C} 7$ & $0.6(3)$ & $\mathrm{N} 1-\mathrm{C} 5-\mathrm{O} 2-\mathrm{C} 6$ & $-174.71(15)$ \\
\hline $\mathrm{C} 8-\mathrm{C} 7-\mathrm{C} 12-\mathrm{C} 11$ & $-1.7(3)$ & $\mathrm{C} 7-\mathrm{C} 6-\mathrm{O} 2-\mathrm{C} 5$ & $-168.20(15)$ \\
\hline $\mathrm{C} 6-\mathrm{C} 7-\mathrm{C} 12-\mathrm{C} 11$ & $173.92(19)$ & $\mathrm{C} 17-\mathrm{C} 16-\mathrm{O} 5-\mathrm{C} 19$ & $-4.5(3)$ \\
\hline $\mathrm{N} 1-\mathrm{C} 1-\mathrm{C} 13-\mathrm{C} 18$ & $137.44(16)$ & $\mathrm{C} 15-\mathrm{C} 16-\mathrm{O} 5-\mathrm{C} 19$ & $176.2(2)$ \\
\hline $\mathrm{C} 2-\mathrm{C} 1-\mathrm{C} 13-\mathrm{C} 18$ & $-107.93(17)$ & $\mathrm{O} 7-\mathrm{C} 20-\mathrm{O} 6-\mathrm{C} 2$ & $-4.1(2)$ \\
\hline $\mathrm{N} 1-\mathrm{C} 1-\mathrm{C} 13-\mathrm{C} 14$ & $-46.17(19)$ & $\mathrm{C} 21-\mathrm{C} 20-\mathrm{O} 6-\mathrm{C} 2$ & $175.16(15)$ \\
\hline $\mathrm{C} 2-\mathrm{C} 1-\mathrm{C} 13-\mathrm{C} 14$ & $68.47(19)$ & $\mathrm{C} 3-\mathrm{C} 2-\mathrm{O} 6-\mathrm{C} 20$ & $85.09(17)$ \\
\hline $\mathrm{C} 18-\mathrm{C} 13-\mathrm{C} 14-\mathrm{C} 15$ & $0.4(2)$ & $\mathrm{C} 1-\mathrm{C} 2-\mathrm{O} 6-\mathrm{C} 20$ & $-157.16(13)$ \\
\hline $\mathrm{C} 1-\mathrm{C} 13-\mathrm{C} 14-\mathrm{C} 15$ & $-176.07(15)$ & $\mathrm{O} 9-\mathrm{C} 22-\mathrm{O} 8-\mathrm{C} 3$ & $2.4(3)$ \\
\hline $\mathrm{C} 13-\mathrm{C} 14-\mathrm{C} 15-\mathrm{C} 16$ & $0.1(3)$ & $\mathrm{C} 23-\mathrm{C} 22-\mathrm{O} 8-\mathrm{C} 3$ & $-176.13(15)$ \\
\hline $\mathrm{C} 14-\mathrm{C} 15-\mathrm{C} 16-\mathrm{O} 5$ & $179.04(16)$ & $\mathrm{C} 4-\mathrm{C} 3-\mathrm{O} 8-\mathrm{C} 22$ & $141.18(15)$ \\
\hline $\mathrm{C} 14-\mathrm{C} 15-\mathrm{C} 16-\mathrm{C} 17$ & $-0.4(3)$ & $\mathrm{C} 2-\mathrm{C} 3-\mathrm{O} 8-\mathrm{C} 22$ & $-108.54(16)$ \\
\hline $\mathrm{O} 5-\mathrm{C} 16-\mathrm{C} 17-\mathrm{C} 18$ & $-179.27(19)$ & & \\
\hline
\end{tabular}

Hydrogen-bond geometry $\left(\AA,{ }^{\circ}\right)$

\begin{tabular}{lllll}
\hline$D-\mathrm{H} \cdots A$ & $D-\mathrm{H}$ & $\mathrm{H} \cdots A$ & $D \cdots A$ & $D-\mathrm{H} \cdots A$ \\
\hline $\mathrm{C} 4-\mathrm{H} 4 B \cdots \mathrm{O} 7^{\mathrm{i}}$ & 0.97 & 2.60 & $3.129(2)$ & 115
\end{tabular}


$\mathrm{C} 6-\mathrm{H} 6 A \cdots \mathrm{O} 1^{\mathrm{ii}}$

0.97
2.54

$3.250(2)$

130

Symmetry codes: (i) $-x+1 / 2, y-1 / 2,-z+3 / 2$; (ii) $-x+1,-y,-z+2$. 